\title{
An outlook on suicide enzyme inhibition and drug design
}

\author{
Mina Hajizadeh ${ }^{1} \cdot$ Zainab Moosavi-Movahedi $^{2} \cdot$ Nader Sheibani $^{3} \cdot$ Ali A. Moosavi-Movahedi ${ }^{1}$
}

Received: 7 August 2021 / Accepted: 24 September 2021 / Published online: 9 October 2021

(c) Iranian Chemical Society 2021

\begin{abstract}
There have been recent renewed interests in the importance of suicide enzyme inhibition. The principal objective of this review is to investigate all types of suicide inhibitions for natural enzymes, artificial biocatalysts as well as therapeutic potential of enzyme suicide inhibition. It is discussed the suicide inhibition beneficial in drug design and treatments and nonbeneficial achievements for some industrial enzymes such as HRP peroxidase enzyme. The design of biomimetic artificial enzymes explained to prevent inhibition by protecting the active site via environmental conditions. Suicide enzyme inhibition development can be the key mechanism against sever diseases such as SARS. In this report, suicide enzyme inactivation classes are classified based on target enzyme groups via their substrates.
\end{abstract}

\section{Graphic abstract}

Suicide substrate deceives enzyme by its shape similarity to normal substrate and after interaction with enzyme, its suicidal functional group appears (e.g., Trojan horse).

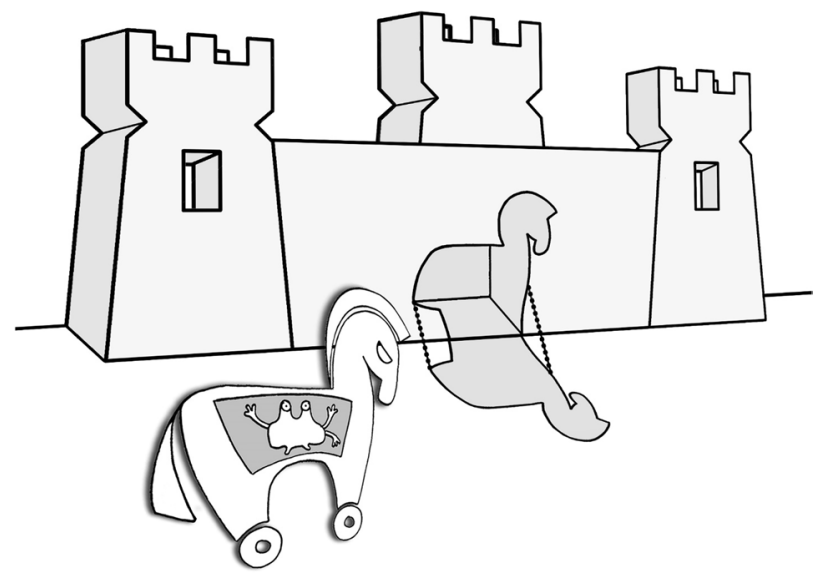

Keywords Irreversible inhibition · Enzymes · Artificial enzymes · Therapeutic potential · Beneficial drug design · Suicide inhibitors $\cdot$ Coronavirus

Ali A. Moosavi-Movahedi

moosavi@ut.ac.ir

1 Institute of Biochemistry and Biophysics (IBB), The University of Tehran, Tehran, Iran

2 Chemistry and Chemical Engineering Research Center of Iran, Tehran, Iran

3 Department of Ophthalmology and Visual Sciences, Cell and Regenerative Biology, and Biomedical Engineering, University of Wisconsin School of Medicine and Public Health, Madison, WI, USA

Abbreviations
$\begin{array}{ll}\text { 3CLpro } & \text { 3C-like protease } \\ \text { ACP } & \text { Acyl carrier protein } \\ \text { ADA } & \text { Adenosine deaminase } \\ \text { ai } & \text { Initial activity } \\ \text { APEs } & \text { Aza-peptide epoxides } \\ \text { C2 } & \text { Secondary carbon atom } \\ E_{0} & \text { Initial enzyme concentration } \\ \text { EI } & \text { Complex enzyme inhibitor complex } \\ \mathrm{H}_{2} \mathrm{O}_{2} & \text { Hydrogen peroxide }\end{array}$

Abbreviations

3CLpro

Acyl carrier protein

ACP

Adenosine deaminase

ai

Aza-peptide epoxides

APEs

Secondary carbon atom

$E_{0}$

$\mathrm{H}_{2} \mathrm{O}_{2}$

Hydrogen peroxide 


\begin{tabular}{|c|c|}
\hline HIV-1 & Human immunodeficiency virus 1 \\
\hline HRP & Horseradish peroxidase \\
\hline$k_{\text {app }}$ & Apparent value of $k$ \\
\hline$k_{\text {cat }}$ & $\begin{array}{l}\text { The number of substrate molecules each } \\
\text { enzyme site converted to product per unit } \\
\text { time }\end{array}$ \\
\hline $\mathrm{Kd}$ & Dimer dissociation constant \\
\hline$K_{\mathrm{i}}$ & Inhibition rate constant \\
\hline$k_{\mathrm{i}}^{\mathrm{app}}$ & Apparent value of inhibition rate constant \\
\hline$K_{\mathrm{m}}$ & Michaelis constant \\
\hline$K_{\mathrm{m}}^{\text {app }}$ & Apparent value of Michaeli constant \\
\hline MERS-CoV & $\begin{array}{l}\text { Middle East respiratory syndrome-related } \\
\text { coronavirus }\end{array}$ \\
\hline MP-11 & Microperoxidase-11 \\
\hline Mpro & Main protease \\
\hline NADPH & $\begin{array}{l}\text { Nicotinamide adenine dinucleotide } \\
\text { phosphate }\end{array}$ \\
\hline $\mathrm{nM}$ & Nano molar \\
\hline $\mathrm{mM}$ & Mili Molar \\
\hline $\operatorname{RdRp}$ & RNA-dependent RNA polymerase \\
\hline$S_{0}$ & Initial substrate concentration \\
\hline SARS & Severe acute respiratory syndrome \\
\hline SDS & Sodium-n-dodecyl sulfate \\
\hline$V_{\max }$ & True maximum rate of the catalytic route \\
\hline$\lambda_{\max }$ & $\begin{array}{l}\text { Maximum value of apparent inactivation } \\
\text { constant for saturating suicide substrate }\end{array}$ \\
\hline
\end{tabular}

\section{Introduction}

Modulators or modifiers are compounds that change the rate of catalyzing enzyme reactions. Commonly, when the effect is to reduce the rate, this is labeled "inhibition" [1]. The inhibition of enzyme activity is the dominant regulatory tool of living cells and one of the critical diagnostic processes for enzymologists [2]. This is of great interest in pharmacological studies [3] and is subject to the condition of interaction between inhibitor, substrate, and enzyme. It is classified as various forms of inhibition [4], including reversible and irreversible inhibition. Each group is divided into subgroups for better understanding. Reversible inhibition is organized into 4 subgroups: competitive inhibition, non-competitive inhibition, mixed inhibition, and uncompetitive inhibition. Irreversible inhibition, which is the main interest of this review, is divided into 2 subgroups: affinity label and mechanism-based inhibitors.

Aspirin is one of the first mechanism-based inhibitors, first discovered in 1899 [5], but its mechanism of action remained undiscovered for many years. In 1965, Ingram and Wood discovered a mechanism to inhibit the enzyme tyrosinase [6]. This is how they described it "we wish to report evidence which seems to support the view that this inactivation is due to the formation of a compound between

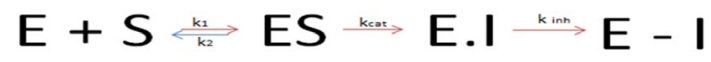

Scheme 1 Suicide inhibition process. The suicide substrate interacts with the enzyme and then converts to the enzyme inhibitor complex by target enzyme. The $k_{\text {cat }}$ plays an important role in this conversion

the enzyme protein and the product of oxidation" [6]. Efforts by other scientists to unravel the mystery of this kind of inhibition continued. Rando finally described this type of inhibition and called it a $k_{\text {cat }}$ inhibitor in 1974 [7], and then found a much more suitable name for this type of inhibition in another article that same year, and call it “mechanism-based inhibition.” In 1975, Carlos H. RamirezRonda named it a Trojan horse inhibition [8]. Finally, in January 1976, a paper presented this type of enzyme inhibition mechanism extensively and named it "suicide inhibition" [9].

\section{Enzyme inhibition}

\section{Irreversible enzyme inhibition}

Irreversible inhibitors usually covalently modify an enzyme [10], and as a result, the inhibition cannot be reversed. When a substance binds strongly to an enzyme so that it can no longer dissociate [11], irreversible inhibition occurs. The kinetics of enzyme irreversible inhibition is often first order [12]. There are two kinds of irreversible inhibition: enzyme-substrate mechanism-based inhibition $\left(k_{\text {cat }}\right.$ inhibitors) and classical affinity labeling agents (active site directed) [13]. Enzyme-substrate mechanism-based inhibition is called $k_{\text {cat }}$ inhibitors (suicide inactivator) as $k_{\text {cat }}$ term is the most important kinetic term in such inhibition (Scheme 1) [14]. Affinity labeling inhibitors are agents in which enzyme binding affinity determines their specificity and effectiveness. In current active site directed reagents [15], the reactive groups are exposed in the solution; hence, they are free to react indiscriminately with any enzyme or small molecule in the solution before reaching its target [16].

As opposed to affinity labels, suicide substrate functional groups are latent in solution and require catalytic uncovering by the target enzyme. This type of inhibitor is the substrate analog that irreversibly ties up with the binding site of an enzyme, deceiving the enzyme by concealing their functional groups. Thus, self-inactivation will occur by the enzyme [16-18]. The substrate, before interacting with the enzyme, is chemically unreactive (Scheme 1). However, the output of the enzymatic modification results in a highly reactive molecule, as a consequence of $k_{\text {cat }}$ inhibition [19]. These types of irreversible inhibition could be ideal for drug design because they are specific for 
the target enzyme [4, 14]. Suicide substrates bring forth the guided enzyme to carry out suicide at some state in its catalytic cycle $[19,20]$. Such inhibitors are specific, because they inactivate only the enzymes that recognize them as substrates. Table 1 shows examples of different suicide substrate and their target enzymes. Suicide substrates could be useful in kinetic, active site, and enzyme mechanism studies [21]. The simplest overall kinetic is illustrated in Schemes 1 and 2, for the inhibitors described above; for affinity labeling Scheme 2; and for suicide inhibition Scheme 1.

\section{Mechanism of suicide enzyme inhibition}

The precise mechanism of inactivation process will differ from one enzyme to another, but the catalytic turnover of the inhibitor is the pivotal occurrence at all times [14]. It is reported that five classes of suicide enzyme inactivation occur. These are categorized by their enzymatically active groups, which are catalytically exposed by target enzymes, namely (1) acetylenes, (2) olefins, (3) $\beta$-substituted amino acids, (4) miscellaneous, which is divided into (A) cyc1opropyl compounds, (b) penicillin derivatives, (c) phenylhydrazine, and (d) nitrilo compounds, and (5) coumarins which are recently added. The two groups of acetylenes and olefins are summarized as below.

\section{Acetylenes}

Acetylenes were the first class of suicide enzyme inhibitors studied, the class described by Bloch and coworkers [51]. They represent $\Delta^{3}$-decynoyl-thioester in the character of the acetylenic analog of one of the substrates of $\beta$-hydroxydecanoyl thioester dehydrase in the synthesis of monounsaturated fatty acids pathway [52]. Several stages in the catalytic cycle of a particular enzyme could convert inactive acetylenic group to an active conjugated allene $[43,53]$. Observations admitted that the enzyme initiates catalysis on the suicide substrate by the regular generation of a $\mathrm{C} 2$ ( $\mathrm{sec}$ ondary carbon atom). The mechanism of inhibition does not only engage alkylation of an enzymatically generated allene (Scheme 3) [54]. There are four suicide enzyme mechanisms in which inert acetylenic group plays a fundamental role: (1) carbanion construction at a neighboring carbon and propargylic reformation to an allene, (2) oxidation of a bordering functional group to a ketone equivalent, or (3) monooxygenation to an oxacyclopropene equivalent, and (4) enzymic exposure of an allenic anion equivalent as nucleophilic, categorized by Walsh [55]. The mechanism for inactivation of cystathionine y-synthase by propargylglycine demonstrates an example of this kind of inhibition (Scheme 4).

\section{Olefins}

Enzymes commonly struggle to carry active site nucleophiles out of sight from the electrophilic intermediates. Nonetheless, when oxidation exposes the reactive performance, mechanism-based alkylative inhibition appears (Scheme 5). Please see the example is Scheme 6.

\section{Conditions that affect suicide enzyme inhibition}

\section{Substrate concentration}

There are two main trackways to study the effects of suicide substrate concentration on suicide inhibition. The first approach is keeping the substrate concentration practically more than enzyme concentration $S_{0}>>E_{0}$, and the second approach uses a lower substrate concentration than enzyme concentration $S_{0}<<E_{0}$. Transient-phase kinetics of enzyme inactivation is illustrated by enzymologists who discovered the solution for time vs. product concentration [57].

$$
S_{0}>>E_{0}
$$

The kinetic behavior of enzyme in the condition of $S_{0}>>E_{0}$ (multi-turnover) occurs through several phases: first: transient phase to a steady state and second: steady state. The consumption of substrate leads to the third phase: transient phase from the over steady state to a sequence of latest steady state. In the last phase, because of diminished substrate, there is no steady state. Also, when an enzyme is present in the presence of a great deal of substrate, this kind of phase will take place, considering the mechanism consists of one catalytic route [57, 58]

$$
E_{0}>>S_{0}
$$

$E_{0}>>S_{0}$ condition lacks the steady state, in such terms; there will be just a transient phase due to substrate consumption. Therefore, the kinetic behavior of suicide substrate under condition $E_{0}>>S_{0}$ (single turnover) could be regarded as a consequence of an overlap in time of two transient phases as a result of the catalytic and inactivation way in this mechanism [57].

Canovas and coworkers studied various conditions with different catechol concentrations $\left(S_{0}\right)$ keeping $E_{0}$ (tyrosinase) and $\mathrm{pH}$ constant [59]. These experiments demonstrated the hyperbolic dependence of "apparent inactivation constant" versus different catechol concentrations, $S_{0}$. The kinetic parameters of the bovine liver catalase by hydrogen peroxide were also determined in our laboratory [60]. The apparent rate constant $\left(k_{\mathrm{i}}^{\text {app }}\right)$ in diverse concentrations of $\mathrm{H}_{2} \mathrm{O}_{2}$ (5.0-20 mM) has been illustrated. These outcomes demonstrated the linearity of $k_{\text {app }}$ in different concentration of $\mathrm{H}_{2} \mathrm{O}_{2}$ [61]. When there is a variation in substrate concentration during the reaction, different kinetic equations should be considered to study suicide inhibition $[62,63]$. 
Table 1 Suicide substrates and their target enzymes

\begin{tabular}{|c|c|c|c|}
\hline Entry & Compound & Enzyme & \\
\hline 1 & $\Delta^{(3,4)}$ decynoyl-N-acetyl cysteamine (NAC) & $\beta$-Hydroxydecanoyl thioester dehydrase & [7] \\
\hline 2 & 2-Hydroxy-3-butynoic acid & Flavin-linked lactate dehydrogenase & [7] \\
\hline 3 & L-serine sulfate & Soluble aspartate aminotrans & [7] \\
\hline 4 & $\beta$-Chloroalanin & Soluble aspartate aminotrans, and L-aspartate- $\beta$ - decarboxylase & [7] \\
\hline 5 & Rhizobitoxine & $\beta$-Cystanthionase & [7] \\
\hline 6 & $\begin{array}{l}\text { L-2-amino-4-methoxy-trans-3-butenoic acid (AMB), } \beta, \gamma \text { - } \\
\text { unsaturated amino acid 2-amino-3-butenoic }\end{array}$ & Pyridoxal phosphate-linked aspartate amino- transferase & [7] \\
\hline 7 & Tosyl phenylalanyl chloromethyl ketone TPCK & Chymotrypsin & [9] \\
\hline 8 & $\mathrm{~B}, \gamma$-Acetylenic & $\Delta^{3,5}$-Ketosteroid isomerase & [17] \\
\hline 9 & $\mathrm{~N}$-propargylglyeine & Sarcosine demethylase & {$[17]$} \\
\hline 10 & 4-Amino-5-hexynoie acid & 7-Aminobutyrie acid (GABA) transaminase & {$[17]$} \\
\hline 11 & Propargylglycine & $\begin{array}{l}\text { Pyridoxal-linked } \gamma \text {-cystathionase and Aspartate aminotrans- } \\
\text { ferase }\end{array}$ & [17] \\
\hline 12 & 1-Methyl-4-phenyl-1,2,3,6-tetrahydropyridine & Monoamine oxidase & {$[18]$} \\
\hline 13 & 3-aminobenzamide & Tankyrase & {$[22]$} \\
\hline 14 & 6-(1S-hydroxy-3- methylbutyl)-7-methoxy-2H-chromen-2-one & Carbonic anhydrases & [23] \\
\hline 15 & Coumarin-3-carboxylate derivatives & Kallikreins 7 & {$[24]$} \\
\hline 16 & 26-Fluorinated $\Delta^{24}$-sterol & Tbsterol C24-methyltransferase & {$[25]$} \\
\hline 17 & 5-Bromoindirubin 3'-(O-oxiran-2-ylmethyl)oxime & Epoxide hydrolase & [26] \\
\hline 18 & 1-Allyl-3,4-methylenedioxy-5-methoxybenzene (Myristicin) & CYP1A2 & [27] \\
\hline 19 & $\begin{array}{l}\text { Foeniculum vulgare, Cinnamomum burmani, and Strychnos } \\
\text { ligustrina }\end{array}$ & CYP3A4 & [28] \\
\hline 20 & Piper nigrum & CYP2D6 & [28] \\
\hline 21 & Tetracyclic sulfenamide & Adenosine 5'-diphosphate receptor P2Y & [29] \\
\hline 22 & $\beta$-Chloroalanine & Alanine racemase & {$[30]$} \\
\hline 23 & 26,27-Dehydrolanosterol (DHL) & Acanthamoeba spp sterol 24-/28-methylases (SMT) & {$[31]$} \\
\hline 24 & 3-Ethylthioprop-2-en-1-ol & Allyl alcohol & [32] \\
\hline 25 & Azaserine & Formylglycinamide ribonucleotide (FGAR) aminotransferase & {$[32]$} \\
\hline 26 & p-Hydroxybenzylcyanide & Dopamine $\beta$-hydroxylase & [32] \\
\hline 27 & 10ß-Propargylestr-4-ene-3,17-dione & Aromatase & {$[32]$} \\
\hline 28 & Vinyl GABA, 4-aminohex-5-ynoic acid & GABA transaminase & [32] \\
\hline 29 & Difluoromethyl DOPA & Peripheral DOPA decarboxylase & {$[32]$} \\
\hline 30 & $\beta$-Aminoacetylenic & Mitochondrial monoamine oxidase & [32] \\
\hline 31 & Benzothiazinones & $\begin{array}{l}\text { Mycobacterial Decaprenylphosphoryl- } \beta \text {-D-ribofuranose 2'-Oxi- } \\
\text { dase DprE1 }\end{array}$ & [33] \\
\hline 32 & DL- $\alpha$-Difluoromethylornithine (D FMO) & Eukaryotic ornithine decarboxylase ( ODC) & [34] \\
\hline 33 & 7,8,4-Trihydroxyisoflavone and 5,7,8,4-tetrahydroxyisoflavone & Mushroom tyrosinase & [35] \\
\hline 34 & Halomethyl dihydrocoumarins & Serine protease & [36] \\
\hline 35 & Benzotriazole esters & Proteinase & {$[37]$} \\
\hline 36 & Serpin1 of Arabidopsis thaliana & Metacaspase 9 & {$[38]$} \\
\hline 37 & Caffeic acid and its n-nonyl ester (n-nonyl caffeate & Tyrosinase & [39] \\
\hline 38 & o-Aminophenols and aromatic o-diamines & Tyrosinase & {$[40]$} \\
\hline 39 & 3-Decynoyl-N-acetylcysteamin & $\begin{array}{l}\text { P-hydroxydecanoyl thioester dehydrase (3-hydroxydecanoyl- } \\
\text { [acyl-carrier-protein]d ehydratase) }\end{array}$ & {$[41]$} \\
\hline 40 & 3-Keto-5,1O-secosteroids & $\Delta^{5}$-3-Ketosteroid isomerase (steroid A-isomerase & [42] \\
\hline 41 & L-2-amino-4-methoxy-trans3-butenoic acid & Aspartate aminotransferase & {$[42]$} \\
\hline 42 & $\beta$-Aminopropionitrile & Collagen cross-linking enzyme & {$[42]$} \\
\hline 43 & 3-Decynoyl-CoA & $\beta$-Hydroxydecanoyl thiolester dehydrase & [43] \\
\hline 44 & Acetylenic secosteroids & $\Delta^{5}$-3-ketosteroid isomerase & {$[43]$} \\
\hline 45 & Ethynylglycin & Alanine racemase & [43] \\
\hline
\end{tabular}


Table 1 (continued)

\begin{tabular}{|c|c|c|c|}
\hline Entry & Compound & Enzyme & \\
\hline 46 & $\gamma$-Acetylenic-GAB & $\begin{array}{l}\text { GABA transaminase, glutamate decarboxylase, ornithine- } \\
\text { 6-transaminas }\end{array}$ & [43] \\
\hline 47 & 4.5-lysyne & Lysine-c-transaminase ornithine- $\delta$-transaminase & [43] \\
\hline 48 & 1.4-Diaminobutyn & Ornithine decarboxylase & [43] \\
\hline 49 & $\alpha$-Ethynylornlthine & Ornithine decarboxylase & [43] \\
\hline 50 & $\alpha$-Ethynyl-OOPA & DOPA decarboxylase & [43] \\
\hline 51 & 3-Butynyl CoA & $\begin{array}{l}\beta \text {-ketoacyl thiolase, Glutaryl CoA dehydrogenase, Butyryl CoA } \\
\text { dehydrogenase }\end{array}$ & [43] \\
\hline 52 & N-pmpynylglycine & Sarcosine oxidase & [43] \\
\hline 53 & Butyne-1-o1, Butyne-1,4-diol & Alcohol dehydrogenase alcohol oxidase & [43] \\
\hline 54 & Ethylene & Liver P-450 monooxygenase & [43] \\
\hline 55 & 19-Propynyl and ethynylestrogen precursors & Aromstase & [43] \\
\hline 56 & Hydroxybutynoate & Several flavin-linked $\alpha$-hydroxy acid oxidizing enzymes & [43] \\
\hline 57 & N-allylgly & Sarcosine oxidase & [43] \\
\hline 58 & Allyl alcohol & Alcohol dehydrogenase & [43] \\
\hline 59 & Vinylglycolat & $\begin{array}{l}\text { L-hydroxy acid oxidase, Enzyme I of hexose phosphotransferase } \\
\text { system }\end{array}$ & [43] \\
\hline 60 & Vinylglycin & $\begin{array}{l}\text { L-aspartate transaminase D-amino acid transaminase L-amino } \\
\text { acid }\end{array}$ & [43] \\
\hline 61 & 4-Trans-methoxy Vinylglycine & L-aspartate transaminase & [43] \\
\hline 62 & 4-Trans-aminoethyloxyvinyglycine & PLP-enzyme in ethylene biosynthesis & [43] \\
\hline 63 & Rhizobitoxi & $\beta$-Cystathionase & [43] \\
\hline 65 & 3-Chloroallylamin & Plasma amine oxidase & [43] \\
\hline 64 & Acrolein & 5-Deoxyribose phosphate aldolase & [43] \\
\hline 65 & $\gamma$-VinylGABA & GAEA transaninase & [43] \\
\hline 66 & cis-4.5-lysene trans-4.5-lysene & Lysine-c-transaminase & [43] \\
\hline 67 & 3.4-Dehydro-L-glutamat & Glutamate decarboxylase & [43] \\
\hline 68 & Allylglycine & Glutamate decarboxylase & [43] \\
\hline 69 & 2-Amino-cis-3-pentenoa & Methionine- $\gamma$-lyase & {$[43]$} \\
\hline 70 & Allylisopropylacetamid & Liver P-450 nmnooxygenase & [43] \\
\hline 71 & $\alpha$-VinylDOPA & DDPA decarboxylase & [43] \\
\hline 72 & $\beta$-Fluoroalanine. D- or L- & Alanlne racemase serfne transhydroxymethylase & [43] \\
\hline 75 & $\beta, \beta$-Difluoroalanine & Alanine racemase & [43] \\
\hline 73 & $\beta, \beta$-Trifluoroalanine & Several PLP-enzymes & [43] \\
\hline 74 & 5-FluoroGABA & GABA transaminase & [43] \\
\hline 75 & $\alpha$-fluoromethylwpa & DOPA decarboxylase & [43] \\
\hline 76 & $\alpha, \alpha$-difluorlxsthyldop & DOPA decarboxylase & {$[43]$} \\
\hline 77 & $\alpha$-Fluoronethyl histidfne & Histidine decarboxylase & [43] \\
\hline 78 & $\alpha$-fluorofmhyl ornithine & Ornithine decarboqvlase & [43] \\
\hline 79 & $\alpha, \alpha$-Difluoromethyl ornithfne & Ornithine decarboxylase & [43] \\
\hline 80 & $\alpha$-Fluoromathyl glutamate & Glutamate decarboxylase & [43] \\
\hline 81 & $\alpha$-Fluoromethylhistidine & Histidine decarboxylase & [44] \\
\hline 82 & 3-Nitropropionic acid & & \\
\hline 83 & 1-Ethynylpyrene & Cytochrome P-450-dependent benzo[a]pyrene hydroxylase & [45] \\
\hline 84 & 2-Bromoethylamine & Semicarbazide-sensitive amine oxidase & [46] \\
\hline 85 & $\beta$-Haloamines & Lysyl Oxidase & {$[47]$} \\
\hline 86 & Vinylglycine (2-amino-3-butenoate) & L-Amino Acid Oxidase & [43] \\
\hline 87 & N-phenylethylenediamine (PEDA) & Dopamine $\beta$-monooxygenase & [48] \\
\hline 88 & 7-Nitro-2,1,3-benzoxadiazole Derivatives & Glutathione S-Transferases & [49] \\
\hline 89 & Androsta-1,4-diene-3,17-diones & Aromatase & {$[50]$} \\
\hline
\end{tabular}


$\mathrm{E}+\mathbf{I} \stackrel{\mathrm{km}}{\mathrm{k}} \mathrm{E} \cdot \mathbf{I} \stackrel{\mathrm{km}}{\longrightarrow} \mathrm{E}-\mathbf{I}$

Scheme 2 Affinity labeling inhibition process

\section{Thermal effect}

Avoiding heat inhibition is a critical issue in enzyme technology. In industrial processes, enzymes may be affected by varying temperatures [10], which could lead to enzyme inactivation and hence restricting enzyme usages. This thermal inhibition could be either reversible or irreversible [11]. The thermal possess could also manipulate flavor, color, and
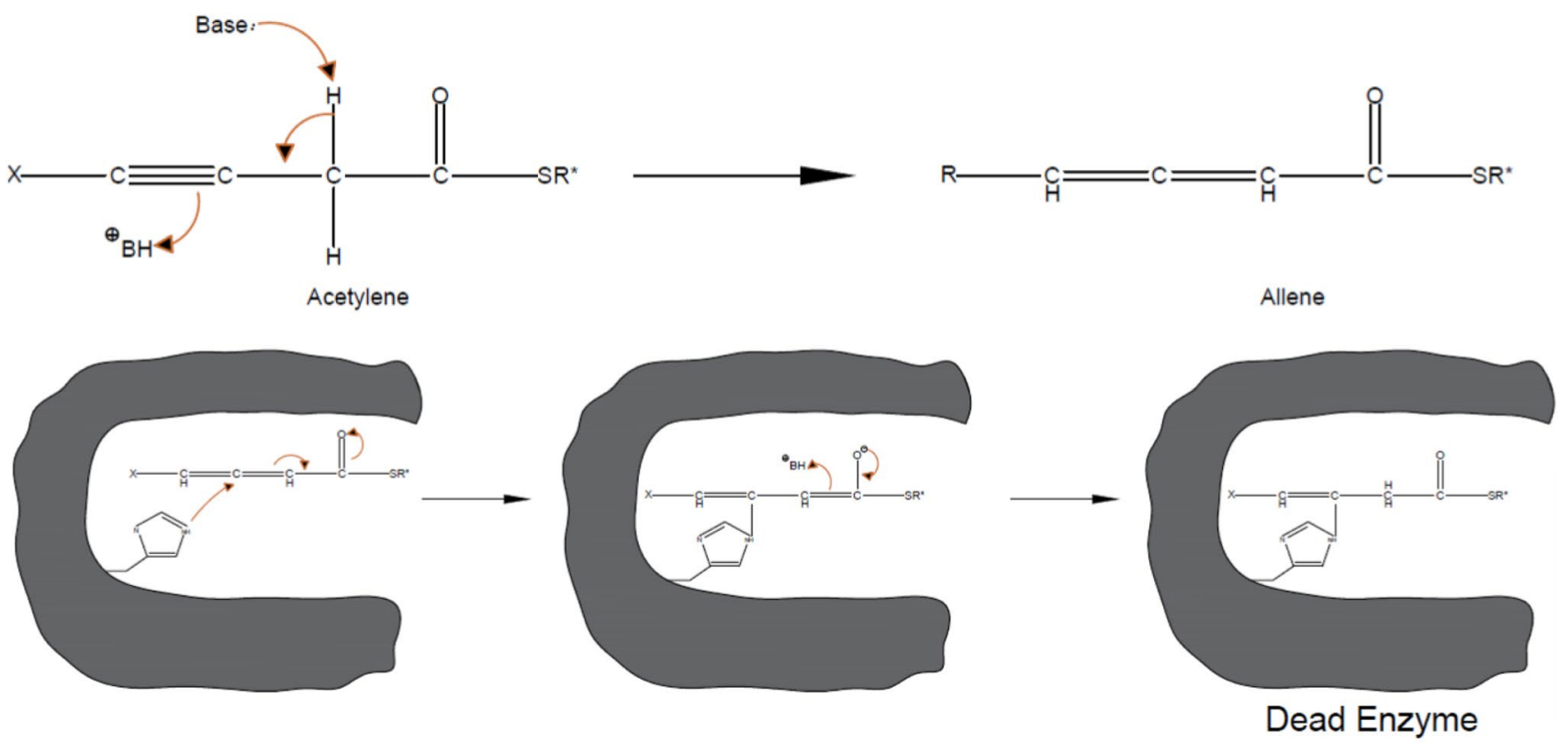

Scheme 3 Mechanism of the inhibition process [56]<smiles>CCC([NH3+])C(=O)[O-]</smiles>
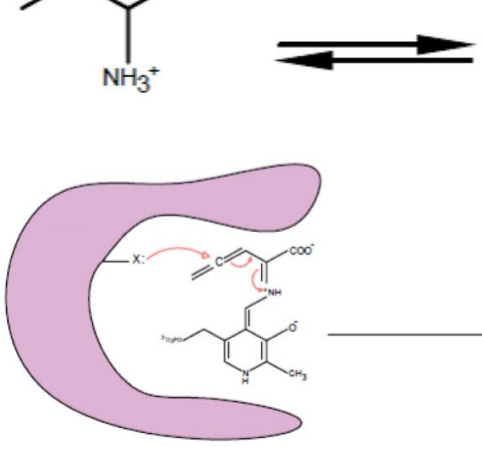
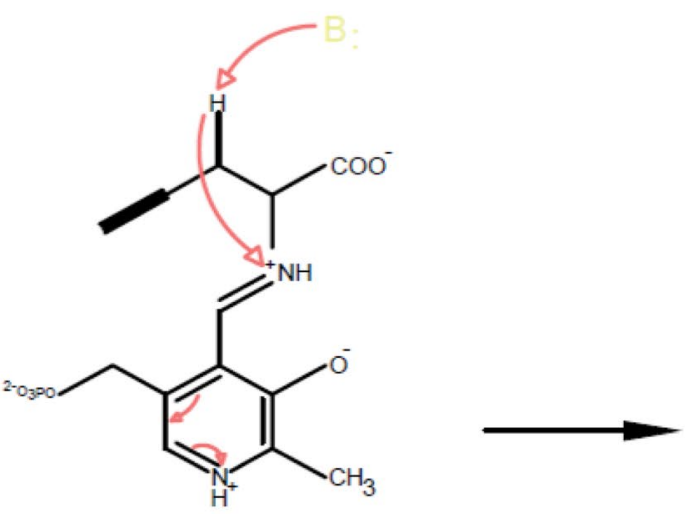

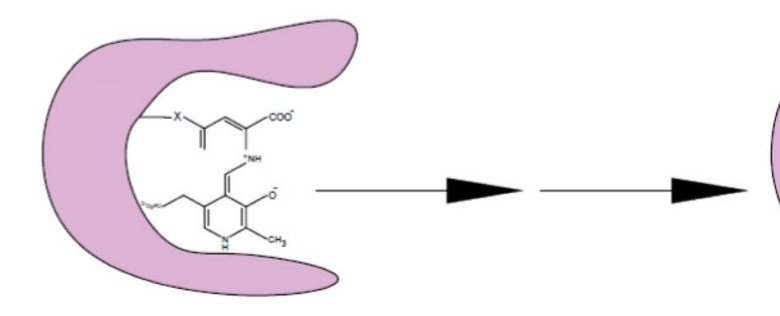<smiles>C=C(C(=O)[O-])[C@H]1C[C@@H](C)[C@H]1PC[Hg]</smiles>
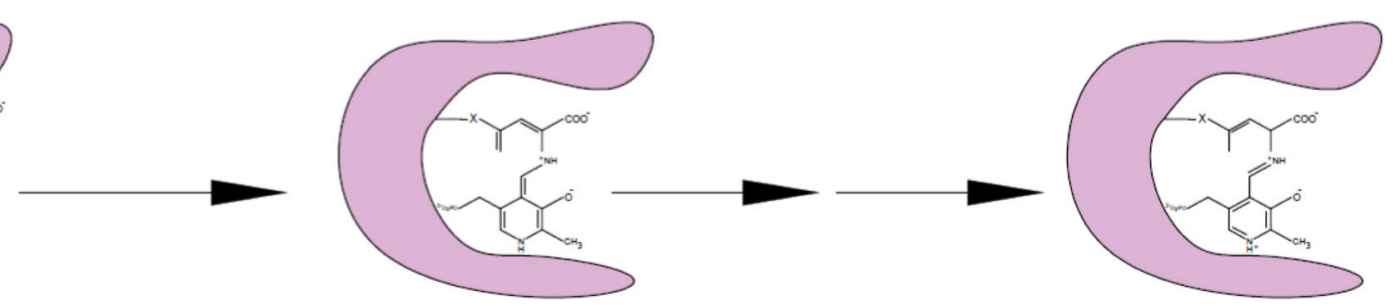

Scheme 4 Mechanism proposed for inactivation of cystathionine y-synthase by propargylglycine [15] 

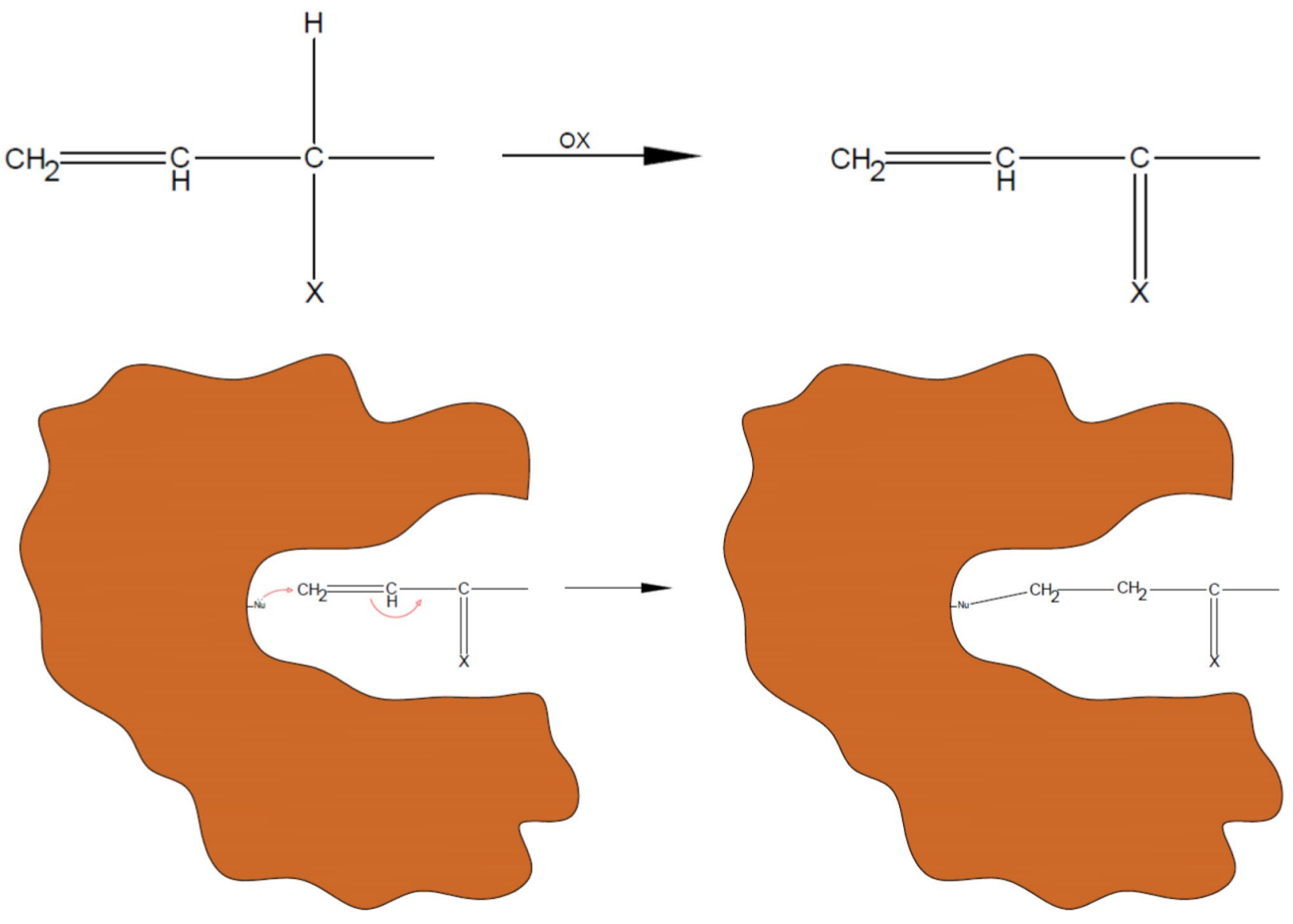

Scheme 5 Mechanism of the inhibition process [57]<smiles>NC1C=CC=C(C(=O)[O-])C1</smiles>

Gabacaline<smiles>CCC[NH3+]</smiles>

GABA<smiles>O=C1C=CC=CC1Br</smiles><smiles>C=CCC1(N=CBr)C=CC=CC1</smiles><smiles>Cc1ccc(C=Nc2ccccc2)c(C(=O)[O-])c1</smiles><smiles>CC(C)Cc1cccc(NCCBr)c1</smiles>

Scheme 6 Mechanism proposed for inactivation of GABA transaminase by gabaculine [15]

texture enzymes. For example, pigments make a significant contribution to perceived color, and its degradation by enzymes, like lipoxygenases can considerably reduce color quality [12]. As demonstrated by Saboury et al. as a matter of caffeine binding to ADA a lower $K_{i}$ value was noted when the temperature was increased by $10^{\circ} \mathrm{C}$. In addition, caffeine binding to ADA is an endothermic process, and the concentration of the EI complex defines the heat value of the reaction [64]. Also, inhibition of mushroom tyrosinase by ethyl xanthate at three temperatures of $10{ }^{\circ} \mathrm{C}, 20^{\circ} \mathrm{C}$, and
$33{ }^{\circ} \mathrm{C}$ demonstrated that the inhibition constant decreased at $33{ }^{\circ} \mathrm{C}$. Thus, the inhibitor has extra affinity for binding to the enzyme at higher temperature [9]. The dissociation binding constant $\left(K_{i}\right)$ could be achieved from thermodynamic and kinetic studies [2]. Furthermore, aspirin and diclofenac are anti-inflammatory drugs, inhibit (suicide inhibition) the activity of adenosine deaminase (ADA), and have diverse effects at diverse temperatures [17].

The heat inactivation process of an enzyme triggers denaturation, which occurs due to interruption of the hydrogen 
bonds and start of enzyme molecule unfolding. Subsequent subunit dissociation, incorrect refolding, and aggregation are factors that can directly cause inactivation. Within this context, when the exposure of hydrophobic sites occurs, aggregation is the consequence and readily appears. Also, denaturation is the aftereffect of aggregation, which leads to enzyme's irreversible configurational change and loss of activity. The temperature and heating time could affect the rate of enzyme inhibition at higher temperatures. The feedback to temperature would occur and follow a biphasic denaturation pattern, thus implying that inactivation arises by various mechanisms each with its temperature dependence, which can be concluded from thermo-inhibition experiments [19]. The graphical fitting method for the measurement of binding constants and enthalpy of binding, based on isothermal titration microcalorimetry data, is easily obtained with high efficiency; this can be used in other systems [65]. Under certain circumstances, the covalent cysteine disulfide bond and the binding of prosthetic groups could have a stabilizing effect $[12,65]$.

\section{$\mathrm{pH}$}

Generally in Michaelis-Menten constant $K_{\mathrm{m}}$ is pH-dependent [66]. The $\mathrm{pH}$ might affect enzymes toward alterations in the binding. It is known that structural matching is a critical key in the binding mechanism, and these structural reshaping in protein-ligand binding has been of primary interest. It is crucial to comprehend the energetic changes of binding-induced protonation state, which can be distinguished as sectional protein unfolding or destabilizing mutations [66]. The $\mathrm{pH}$ effect on enzyme or substrate, by globally changing the conformation of the protein, is a cause of altered protonation state of the titratable groups during individual reaction and leads to $\mathrm{pH}$ dependence of protein stability. These changes are essential for structure-based drug design, practical and automated ligand docking, and affinity ordering methods [66].

As mentioned before, $\mathrm{pH}$ can affect $\mathrm{Km}$ and also could affect turnover number $\mathrm{k}_{\mathrm{cat}}$ (the number of substrate molecules each enzyme site converts to product per unit time) by changing the actual catalysis of the bound substrate [67]. The outcome of the $\mathrm{pH}$ effect on the suicide inactivation of frog epidermis was investigated by Garcla Moreno. Kinetic studies indicated that the kinetic constant $\lambda_{\max }$ (maximum value of apparent inactivation constant for saturating suicide substrate) does not change along with the $\mathrm{pH}$. The independence of $\lambda_{\max }$ against $\mathrm{pH}$ is the evidence of benefaction of steady-state steps. The nonlinear fall of $K_{\mathrm{m}}$ app (apparent $\mathrm{Km})$ versus $\mathrm{pH}$ data has demonstrated an excellent fit by nonlinear regression [68]. Cánovas and coworkers noted the catalytic and inactivation stages do not depend on the protonation/deprotonation of the enzyme. Their research on the suicide inactivation of tyrosinase demonstrated that the dependence of tyrosinase to catechol diminishes with $\mathrm{pH}$ [59].

\section{The effects of nanobiocatalysis components and amino acids}

For illustrating nanobiocatalysis effects, hemoprotein models could clarify that the complex associations are the best choice. Heme-based mini enzymes or microperoxidases are the latest types of biocatalysts and hemoenzyme models. Microperoxidases have peroxidatic activity such as HRP and cytochrome C. Microperoxidase-11 (MP-11) is a polypeptide consisting of the active site microenvironment of cytochrome $\mathrm{c}$ and a heme prosthetic group, and MP-11 can simulate peroxidase oxidation reactions. MP-11 is more water-soluble and has a lessened shift to aggregate/dimerize, and a dimensional configuration than a simple heme. Identical to peroxidases, the heme group in MP-11 is exposed to the solvent. In all hemoproteins, including peroxidases "suicide-peroxide inactivation" pathway initiates in high concentrations of hydrogen peroxide. A high concentration of hydrogen peroxide likewise can inactivate microperoxidases and then the peroxidases as a result of uncovered heme group [69]. When catalase meets $\mathrm{H}_{2} \mathrm{O}_{2}$, the bovine liver catalase reaction triggers. At first, the decay of $\mathrm{H}_{2} \mathrm{O}_{2}$ by catalase appears in line with the catalytic cycle. Further, inhibition of catalase through commutation of two-electron-oxidized state (compound I) to other oxidized model of catalase (compound II) by interior electron donors takes place. Derivatives of compound II and compound II itself are catalytically passive. Consequently, the active enzyme gently quits from the catalytic cycle and this action leads to suicide inactivation [60].

Cyanide and azide ions, sodium-n-dodecyl sulfate (SDS), 2-mercaptoethanol, 3- aminotriazole, and NADPH influence on the initial activity (ai), inhibition rate constant $\left(k_{\mathrm{i}}\right)$ and the partition ratio $(r)$ of bovine liver catalase reaction with its suicide substrate hydrogen peroxide were investigated. Cyanide and azide ions, which consist of rapid and reversible inhibitors of catalase, resulted in a decline in ai and $k_{\mathrm{i}}$ but $r$ remained constant. In sodium-n-dodecyl sulfate (SDS) and 2-mercaptoethanol samples, which result in gradual and irreversible inactivation of catalase for a settled time, a decrease in ai and perseverance of $k_{\mathrm{i}}$ and $r$ were recognized. The 3-aminotriazole could incorporate with intermediate compound I, and as a consequence, ai was almost unchanged although a rise in $k_{\mathrm{i}}$ and a fall in $\mathrm{r}$ were noted. In NADPH effector, which diminishes compound I to Ferri catalase, ai was not changed considerably. However, a bit of decline in $k_{\mathrm{i}}$ was observed that was related to a rise in $r$. The outcome demonstrated reliable detection of variable effectors influence and determined the kinetic parameters of catalase in 
different approaches. Therefore, the measurement of these parameters by simple kinetic analysis can be accomplished for the classification of the agents which affect the kinetics of catalase [70].

To declare the value of the certain reagents, the recombinant proteins have disclosed the importance of the amino acid residues that are essential for catalysis. The wisdom of the full protein sequence led to the identification of the positions of these special amino acids [71]. HRP isozyme $\mathrm{C}$ is a single-chain glyco-hemoprotein containing 308 residues. HRP has an alpha-helical structure which consists of eight helices when the heme group is inserting tight between two helices. The presence of Arg 38, Tyr 185, and 8-CH3 group of the pyrrole (IV) provides an appropriate environment for aromatic substrates to bind effortlessly close to the heme group. These results demonstrated that the existence of a His amino acid leads to substrate alteration of a boost around 1.8 times. This explains the presence of increased prosperous enzyme under suicide-peroxide inhibition conditions.

Some amino acids (His, Tyr, and/or Cys) of HRP increase the activity of HRP, and these amino acids cover the peroxidase as opposed to the suicidal inhibition influence of peroxide. This strategy could be the perfect way to protect the peroxidase as oppose to suicidal inactivation influence of peroxide and could be used in the enzymatic assays and biotechnological applications of HRP. When looking for a natural and biocompatible compound, which has an enzymatic structure, amino acids could be the best choice. They are non-toxic and can be used with good preference as a valuable option for the known metallic, inorganic, and/or organic efficient stabilizers even in in vivo studies [72]. Another example of demonstrating the importance of amino acids in suicide enzyme inhibition is the biotin pathway. Biotin is a cofactor of enzymes which participate in a variety of metabolic procedures as well as carbon dioxide transformation in fatty acid biosynthesis, amino acid metabolism, and gluconeogenesis. The biotin pathway includes two main steps. Step 1: synthesis of pimeloyl- ACP. Bio F, bio A, bio $\mathrm{D}$ and bio $\mathrm{B} 6$ encode enzymes to start step 2 by converting first-step products (pimeloyl) to biotin, but sometimes operon slr0355 (named bio U) can form instead of bio A. Bio $\mathrm{U}$ encodes a single-turnover suicide enzyme, and bio $\mathrm{U}$ uses its Lys 124 residue as an internal amino donor to converts 8-amino-7-oxononanoate to DAN-carbamic [73].

\section{Design of drugs as suicide enzyme inhibitors: advantages and disadvantages}

Drugs are fundamental to the prevention and treatment of diseases, and ideal medications are very desirable [74]. The actions of large number of drugs are associated with enzyme inhibition. In the 1970s, the main efforts of researchers were in the design of the suicide inhibitor paths to establish highly selective enzyme inhibitors as drugs. This cleared the way for undesirable reactions with other biomolecules. Because of their great specificity, inhibitors of this type ought to be a useful starting point in rational drug design [75]. The design of selective covalent inhibitors is theoretically tempting, but in practice tough to accomplish. This has something to do with the fact that it is hard to attain the appropriate harmony within reactivity and selectivity. This method prevents the direct use of a highly reactive specie, which could randomly react with different macromolecules [29].

The main attempt in suicide substrate design is to construct a higher reactive chemical variety than the typical reaction intermediate or covalently bound in the active site. The primary structural physiognomy of the designed inhibitors should increase the binding energy, and the reaction of the functional group selectivity for a given enzyme type should be the utmost intention. In addition, the intermediate must be as reactive to the covalently modified residue in the active site or coenzyme. A low partition ratio of the product molecule formed per enzyme molecule inactivated could be useful in identification of product molecules that can diffuse from the enzyme and harm other cellular constituents [76]. The potential of specific drugs is obvious, and investigation of suicide enzyme inhibition led the way to design many useful drugs [77]. Undeniably, inactivation and deficiency of the enzyme activity by its suicide substrate are the major limiting factor in such reactions. This finally leads to ending the reactions that require extra usage of fresh enzyme solution to complete the reaction.

Nowadays, suicide substrates have been used for inflammation-related diseases [25, 78], anti-parasitic agents [25, $34]$, cancer [22, 26, 79], bacterial infections, neoplastic diseases [21], antibiotic [41], biosensors preparations and biotechnological applications [72], HIV-1 cardiovascular disease, diabetes, viral infection, bacterial infection, antidepressant drug, skin diseases [24], and neurodegenerative diseases [80]. Also, suicide enzyme inactivators are used for "reverse metabolomics" approach to trace back from a known substrate or its metabolite(s) to the protein catalyzing the bioconversion for the identification of enzymes and the genes encoding them [16]. There is a strong reason for using suicide enzyme inhibitors as highly specific clinical agents. These reagents are chemically inactive until altered specifically by the marked enzyme; thus, displeasing processes with foreign biomolecules are prevented [76]. The inadequacy of these inhibitors shows off because they are intrinsically reactive molecules. They may react with other active sites of the given enzyme or react with molecules exclusive of the target enzymes, especially in vivo inhibitors [9]. There is hope for tumor growth inhibition by specific enzyme inhibitors to find a better way to effectively mitigate tumor growth. Designing specific enzyme inhibitors needs extensive investigation. Thus, it is hard to find an enzyme 
that is fundamental for a tumor cell but not for normal cells [81].

In 1982, Vane, Samuelsson, and Bergström were awarded the Nobel Prize for clarifying the aspirin's mechanism of action in 1971 [82, 83]. Aspirin is a nonsteroidal anti-inflammatory drug, and its anti-inflammatory effects are a consequence of the inhibition of cyclooxygenases (COX)-1 and COX-2 enzymes [83]. Platelets are one of the most important components of natural hemostasis and a major participant in terms of their ability to adhere to damaged blood vessels and accumulate at injury sites [84]. Although the adhesion and activation of platelets as a physiologic response to repair, the sudden rupture of atherosclerotic plaque will accelerate its progress. Failure to control this process, through a series of ring amplifier homeostasis, can lead to the formation of thrombus in the intestine, transient vascular occlusion, and ischemia or infarction.

Obviously, platelets have a crucial part in natural hemostasis in the body and the pathogenesis of the atherothrombotic disease. Platelet pathological and physiologic functions cross the same road; thus, it is difficult to classify the remedial assistants from adverse effects [84]. Anti-platelet drugs participate in some steps of the activation process, including adhesion, secretion, accumulation, and have a considerable effect on the possibility of arterial thrombosis that could not be sorted out from the higher possibility of bleeding. The purpose of anti-thrombotic treatment is to raise the effectiveness and lower the possibility of side effects. Thus, nowadays anti-platelet treatment is common for preventing acute thromboembolic artery blockage in cardiovascular disease [82]. This is due to increased platelet activity and inhibition of the release of platelet-derived vasoactive mediators, possibly due to endothelial dysfunction.

Despite advances in our understanding of platelet function, aspirin still remains a popular drug. Suicide inhibition of cyclooxygenase (COX)-1 and, as a consequence, inhibition of the prostaglandin $\mathrm{H} 2$ generation (a precursor of thromboxane A2) are the most important step as aspirin's mechanistic signature (Fig. 1). COX-1 and COX-2 catalyze the first reaction in prostanoid biosynthesis, which modifies arachidonic acid to PGH2. PGH2 is the precursor of PGD2, PGE2, PGF2 $\alpha$, PGI2, and TXA2 [84]. COX-1 and COX-2 are homodimer enzymes with a molecular weight of approximately $72 \mathrm{kDa}$. The molecular mechanism of irreversible inhibition of COX by aspirin is associated with the closure of COX channel by acetylation of a strategically positioned serine residue [85] (see Fig. 2). This reaction prevents the substrate access to the catalytic site of the COX. Thus, aspirin irreversibly inhibits the pathway that makes prostaglandin H2. TXA2 gives raise to platelet aggregation and
Fig. 1 Arachidonic acid metabolic pathway [86], COX-1 cyclooxygenase 1, COX-2 cyclooxygenase 2 , TXA2 Thromboxane A2, PGI2 prostaglandin I2

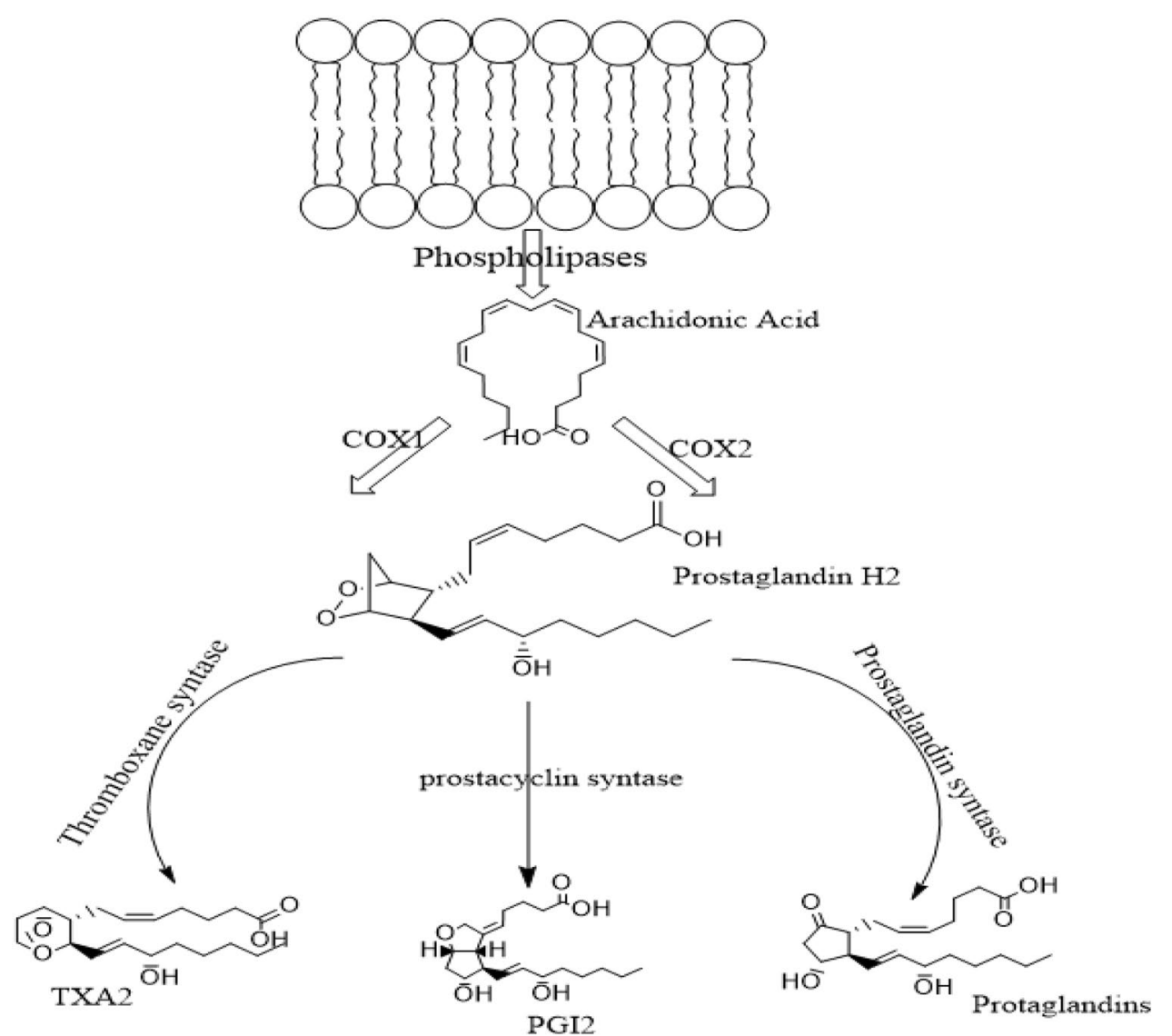




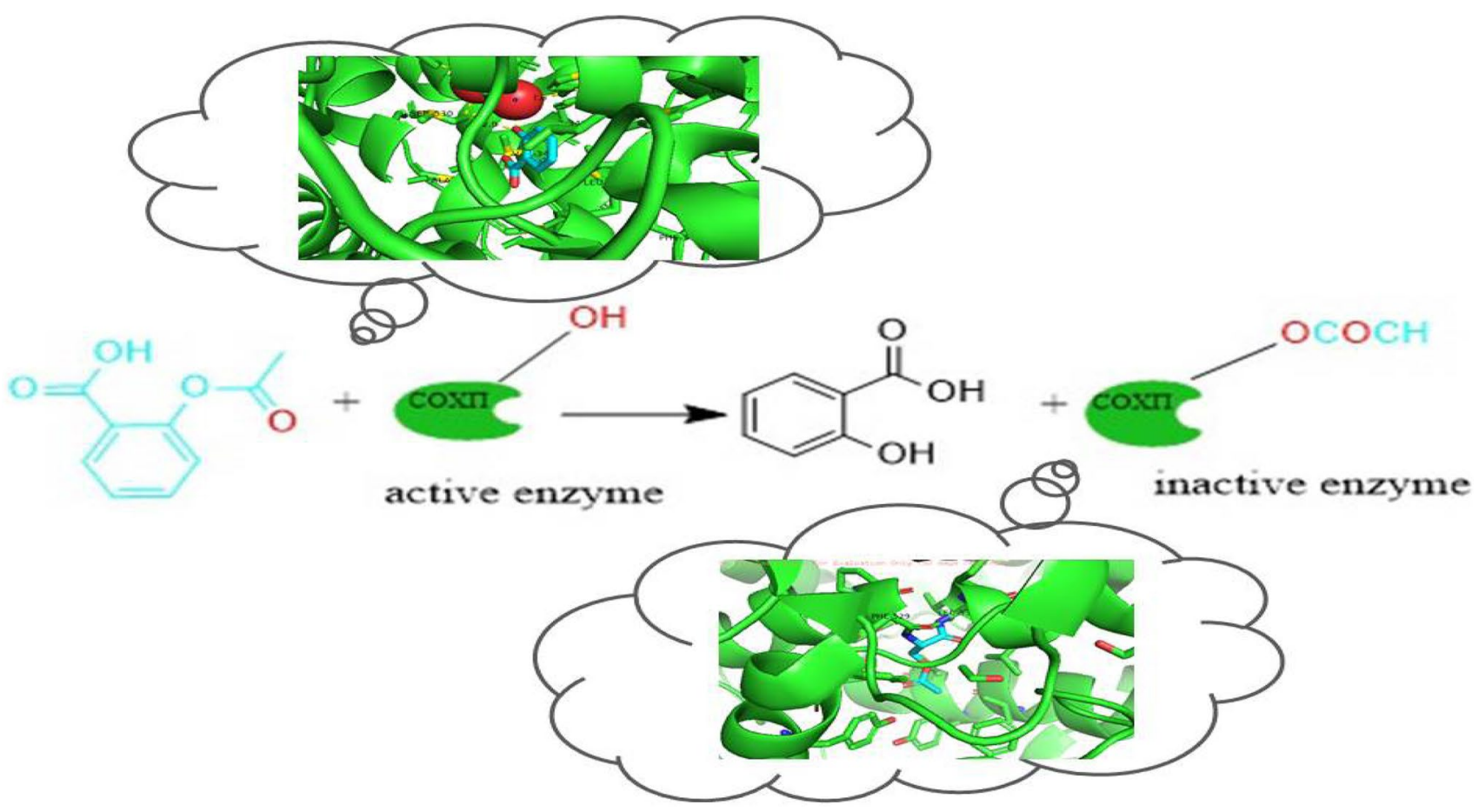

Fig. 2 Aspirin mechanism of action (acetylation) [85], COX-2 cyclooxygenases 2

vasoconstriction, whereas PGI2 inhibits platelet aggregation and increase vasodilation (Fig. 1). Until today aspirin has been the fundamental anti-platelet therapy [86] (Table 2).

\section{Suicide inhibition drug design for coronaviruses}

The appearance of the 2019 novel coronavirus (2019- nCoV) caused many infections and fatalities. Coronaviruses have been known since 1947. Till now many anti-viral agents have been identified to inhibit SARS (severe acute respiratory syndrome) in vitro, but none of them have received FDA approval for the treatment of SARS [87]. However, the therapies are aimed concerning symptomatic alleviation [88]. Ongoing SARS studies revealed some inhibition approaches with micromolar to nanomolar activity [87]. Variable segments of the virus can be the target for inhibition such as 3CLP, PLP, RNA-dependent RNA polymerase (RdRp), and the 50-30 helicase, E protein (Orf4), M protein (Orf6), and $\mathrm{N}$ protein (Orf9) [89].

The nsp5 protease (aka 3C-like protease, 3CLpro), also known as the main proteinase (Mpro), plays an important role in replication of all coronaviruses; during 3CLpro cleavage action, the coronavirus polyprotein remains in 11 conserved sites in the central and C-proximal regions of the two polyproteins [90]. 3CLpro is a cysteine protease that owns a cysteine-histidine catalytic dyad at its active site and cleaves a Gln-(Ser/Ala/Gly) peptide bond [91]. The protease contains three domains, and the active site is located between domains I and II [92]. An important role of Mpro in the coronavirus life cycle made it a desirable point to design anti-CoV drugs [93]. Kinetic, biophysical, and X-ray structural studies provided that SARS-CoV 3CLpro is only active in vitro as a tightly associated dimer, with a dimer dissociation constant (Kd) in the low $\mathrm{nM}$ range [38] CysHis catalytic dyad is placed in a cleft enclosed by domains I and II. The N-terminal residues 1-7 of Mpro play a major part in the proteolytic activity. The C-terminal domain III is responsible for dimerization.

Additional studies have revealed critical inhibitors, N3, N27, and H16, with effective inhibition opposite to SARSCoV Mpro. The inhibition is through preventing the activity of the Mpro over a standard Michael addition reaction. The standard suicide inhibitor label of Michael acceptor inhibitors (N3) comes from its irreversible interaction with the active site of the enzyme. Besides, noticeable structural flexibility in the inter-domain linker region cling to the idea that fixing the loop region into a definite conformation could arrange a new strategy to prevent the activity of $\mathrm{CoV}$ polyprotein $[93,94]$. Also, Lee and coworkers reported that aza-peptide epoxides (APEs) have the attractive capability as inhibitors of SARS-CoV Mpro and are worthy of further evaluation in the development of lead compounds for antiSARS agents [95]. The X-ray crystal structure of the SARSCoV 3CLpro with the benzotriazole ester demonstrates that this class of active site cysteine is acylated by benzotriazole ester ligand and acts as a suicide inhibitor. Structural 


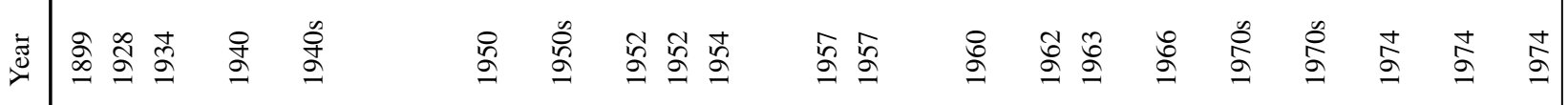

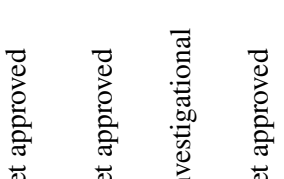

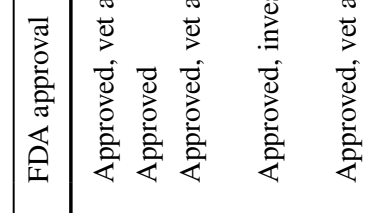

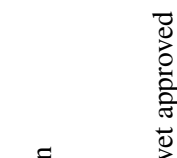

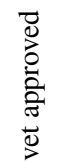

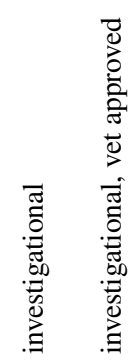

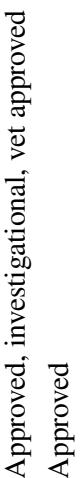

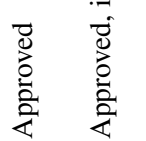

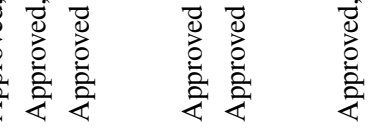
ये द्ये

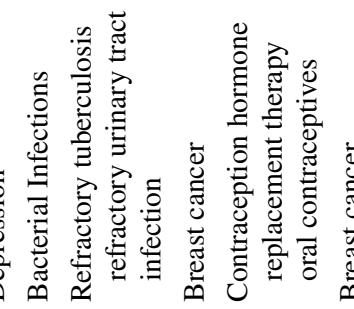

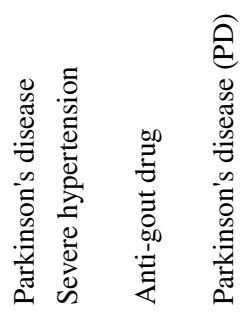
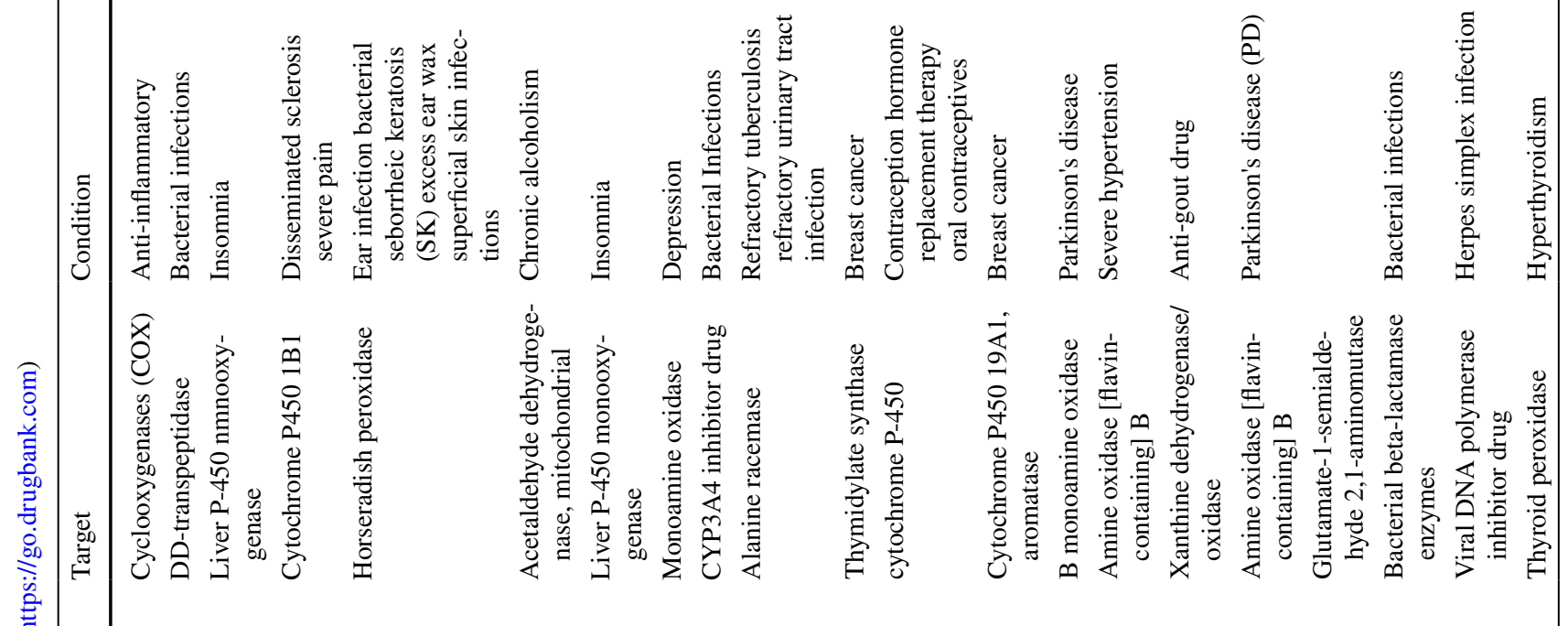

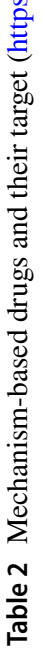

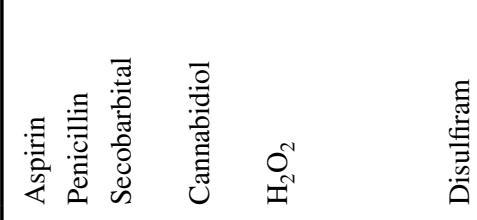

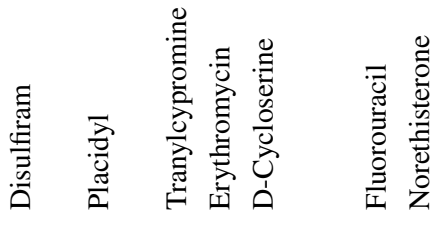

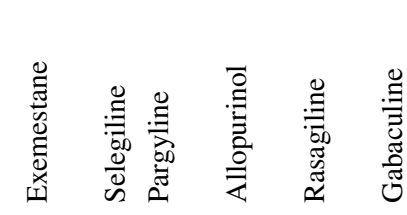

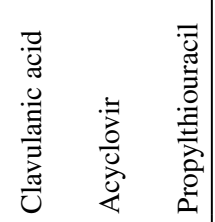




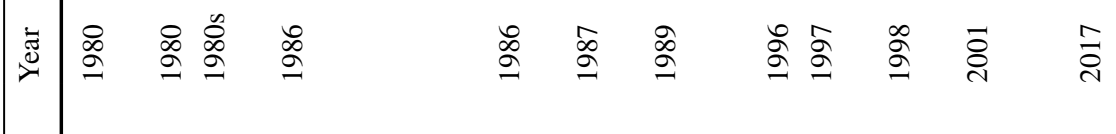

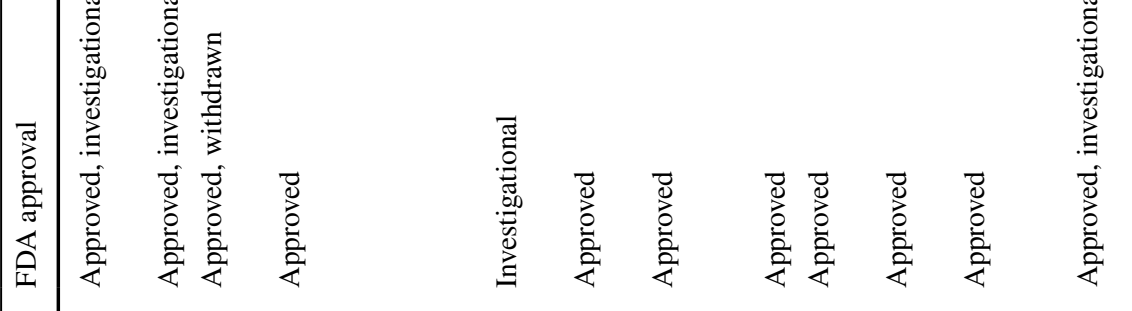

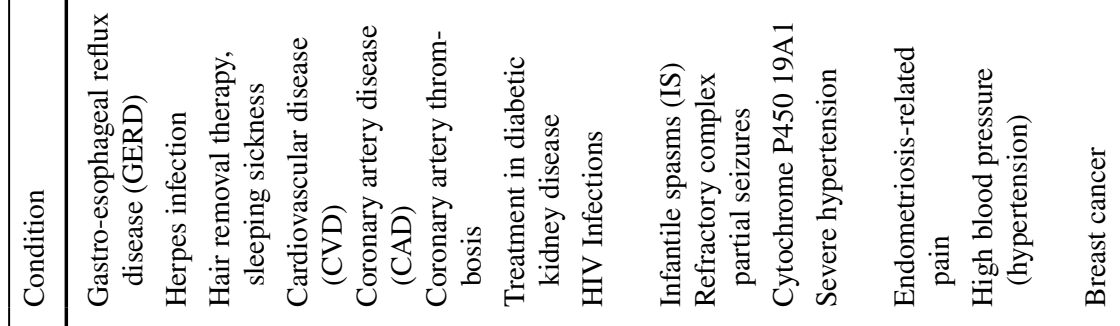

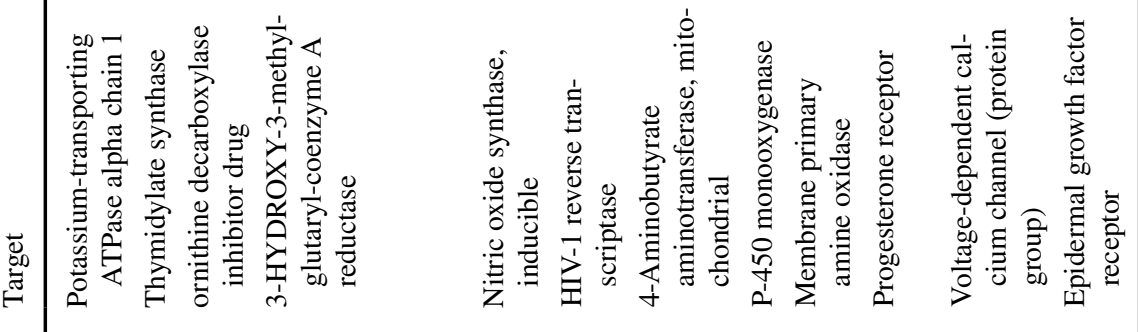

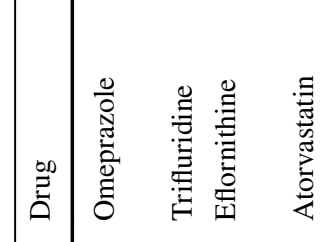

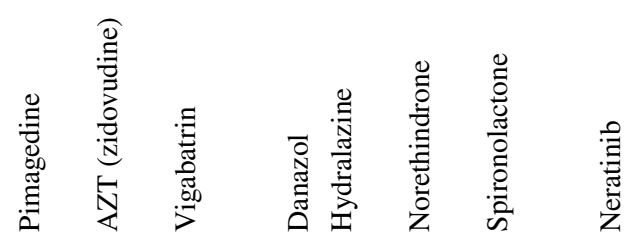

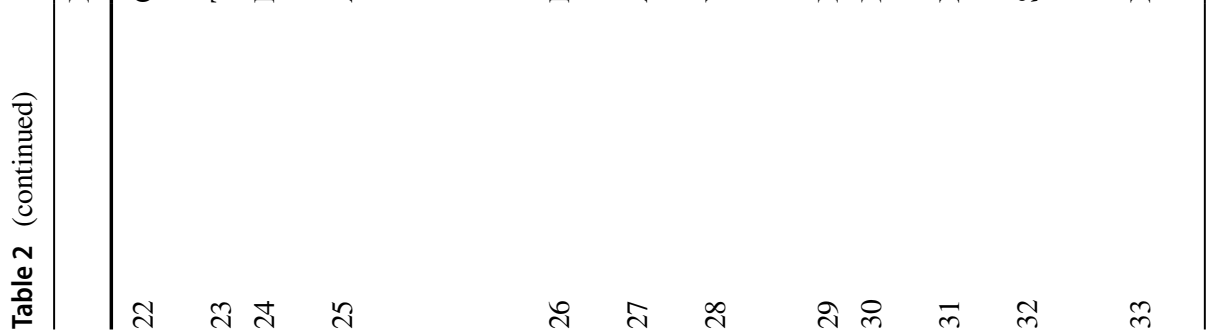


similarity between SARS-CoV and MERS-CoV 3CLpros causes the possibility that 3 CLpro inhibitors like CE-5 will be cross-reactive and have inhibitory characteristics facing MERS-CoV 3CLpro [96]. The heteroaromatic ester 119 was also identified as a potent inhibitor of the SARS coronaviruses. The 5-chloropyridine moiety in compound 119 plays a major role as opposed to SARS-CoV 3CLpro [87]. For viral infection treatment, it should be taken into the consideration that the capability of viruses to promptly evolve and slip away the treatments through multiple and diverse mechanisms of resistance are a great challenge for drug design [97].

\section{Commercial applications}

Enzymes are biocatalysts and their widespread usage on an industrial scale varies from easy reaction conditions to their exceptional product selectivity [98]. Enzyme catalysis benefits have been used in the pharmaceutical, food and beverage, detergent, and biofuel industries for many years. In recent years, biotechnology scientists are taking steps to utilize the advantage of enzyme catalyst in new industries such as fossil fuel conversion and fine chemical production. In industrialscale chemical production, the advantages of biocatalysis are often versatile because biocatalysts are economical and environmentally safe [99].

Hence, when an enzyme is used to achieve the desired effect, it must be under control to prevent the formation of other unwanted products [98]. One of the methods used in industry to combat the harmful effects of enzymes is the use of enzyme inhibitors. Through to enzyme importance in the market (Fig. 3), it makes enzyme inhibitors very critical substances in the industry. Enzyme inhibitors still are the most common way to discover the pathways of enzymatic reactions. Different kinds of biochemical inhibitors like poisons have been engaged by scientist toward determining the active involvement of microbes in chemical reactions occurring in natural samples. Specific inhibitors provide powerful experimental tools for commercial applications in agriculture and industry. Endeavor to develop pesticides and microbial inhibitors for commercial applications introduced several routinely used specific inhibitors. Selective inhibition is not a new approach, however. Selective physical treatments like heating have been used but to reach the utmost specificity chemical inhibitors become more interesting.

The use of inhibitors in the industry has a broad spectrum that it would be impossible to document all those applications [98]. It is not the intent of this review to establish an exhaustive listing of all types of industrial inhibitors. Instead, here we have primarily emphasized suicide inhibitors used for industrial ambitions. Post-harvest browning is a common phenomenon in crops such as mushrooms, which reduces the commercial value of crops [100]. The complete path of pigment production is shown in Fig. 4. The most important step in this pathway is the reaction in which tyrosine becomes dopaquinone (Fig. 4); this reaction is catalyzed by tyrosinase. Hyperpigmentation in human skin and enzymatic browning in fruit is not a desirable process. This occurrence has opened a new door to competition in foods and cosmetics industry to find the right inhibitor for tyrosinase. Plenty of tyrosinase inhibitors have been detected from both natural

Fig. 3 Global enzyme markets (data in millions) [99]

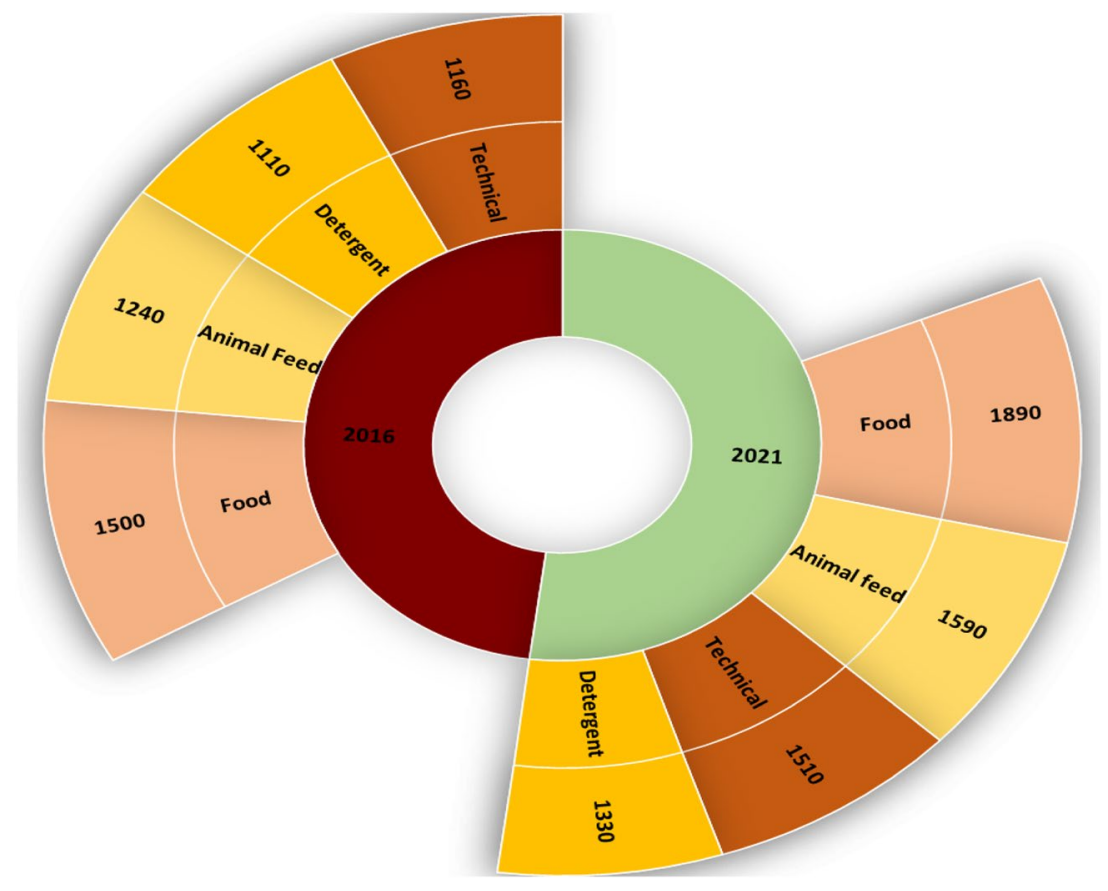




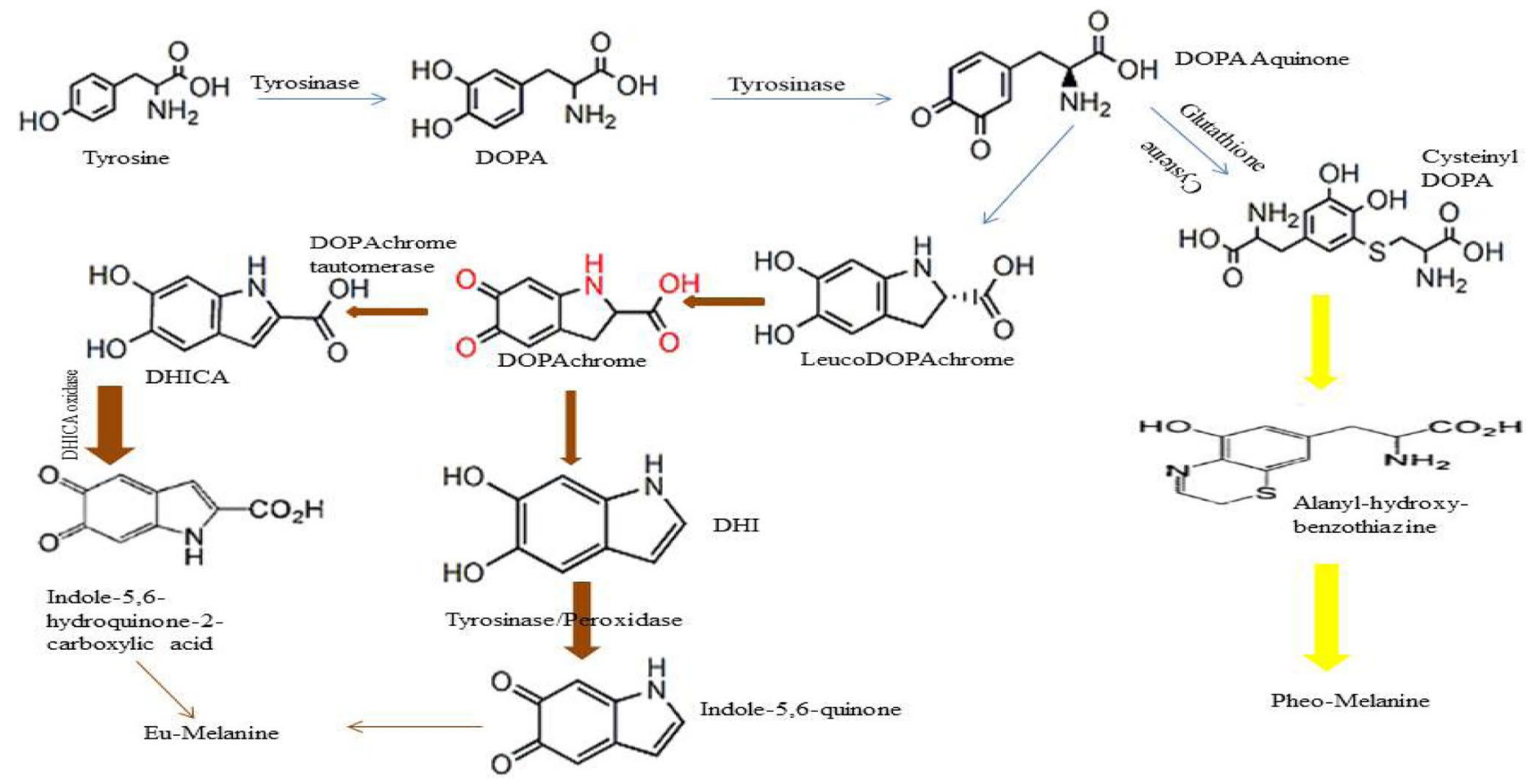

Fig. 4 Biosynthetic pathway of melanin. DOPA, 3, 4 dihydroxyphenylalanine; DHICA, 5, 6-dihydroxyindole-2-carboxylic acid; DHI, 5,6-dihydroxyindole [103]

and artificial sources, but naturally occurring tyrosinase inhibitors is of great industrial interest [101, 102]. Fungi tyrosinase enzyme activity could be inhibited by resveratrol (3,5,40-trihydroxytrans-stilbene, 9), resveratrol act as a suicide inhibitor for fungi tyrosinase enzyme, and this inhibition blocks tyrosinase to catalyze tyrosine to dopaquinone [100]. Also, there are other suicide substrates for tyrosinase, some of which are mentioned in Table 1.

Lafutidine is known as a histamine $\mathrm{H} 2$ receptor antagonist drug. In lafutidine manufacturing, there was $1.5-2 \%$ impurity, the main part of this impurity consists of dihydro lafutidine. Using 1-hexene as a suicide substrate to inhibit the formation of dihydro lafutidine in the synthesis of lafutidine decreased the impurity from $1.5 \%$ to less than $0.05 \%$, demonstrating the effectiveness of suicide substrates for reducing the formation of the relevant byproducts in drug production [104].

Suicide substrates have also been used in protein production. A popular strategy for screening clones with the favored gene is to use media components that are suicide substrates by enzymatic turnover of the knockout target [105]. This toxin ensures that only organisms that have knockout of targeted gene survive because they are not able to produce a suicide substrate product. Fluorouracil is one of the most commonly used compounds [106]. Similarly, suicide substrates are used to isolate proteaseresistant mutations to improve heterogeneous protein production [107].

\section{Improvement in nanobiocatalyst design along with their suicide inhibition}

Some peroxidase-like nano artificial enzymes are designed to diminish or put an end to the suicide inhibition in peroxidative reactions, such as vesicular mixed gemin-SDS-hemin-imidazole complex and microperoxidase-11/ $\mathrm{NH}_{2}$-FSM16. Vesicular mixed gemin-SDS-hemin-imidazole complex did not exhibit suicide inactivation except at high concentrations of hydrogen peroxide because vesicle hydrophobic pocket productively covered the active site, which regulates the concentration of hydrogen peroxide at the heme moiety and enabling high rates of enzymatic turnover [108]. As mentioned before, in MP-11 heme group is exposed to the solvent, which leads to suicide-peroxide inactivation. Thus, in microperoxidase-11/NH2-FSM16 heterogenization of a biocatalyst through covalent immobilization in a folded sheet nanostructure with a protective effect of the engineered nanopores provides a potent peroxideresistant peroxidase [109]. To improve catalytic efficiency of HRP in the presence of $\mathrm{H}_{2} \mathrm{O}_{2}$, caseoperoxidase (mixed $\beta$-casein-SDS-hemin-imidazole complex) has been designed, which is HRP-like enzyme consists of Camel $\beta$-casein-SDS. Caseoperoxidas protects HRP's active sites by one main electrostatic and four minor non-electrostatic (hydrophobic) sites of $\beta$-casein [110]. To determine the protective effect of camel $\beta$-casein, heme-imidazole-SDS 
nanobiocatalyst was designed and compared with caseoproxidase through the suicide parameters [111].

\section{Conclusion}

This study was performed to investigate in detail the information available on suicide inhibition. One of the most important of this study is to find a large number of enzymes that inhibit in a specific active site that play a role in recognizing of some diseases, including cancer and understanding the foresight of such diseases. It is important to advance the knowledge and understanding of suicide control in order to determine strategies for controlling enzyme activity in various programs.

Acknowledgements The support of the University of Tehran and Iran National Science Foundation (INSF) is gratefully acknowledged. We are also grateful to Mahdie Rahban for her valuable assistance.

\section{References}

1. A.A. Saboury, J. Iran. Chem. Soc. (2009). https://doi.org/10. 1007/bf03245829

2. M. Umar Dahot, A.A. Saboury, A.A. Moosavi-Movahedi, J. Enzyme Inhib. Med. Chem. (2004). https://doi.org/10.1080/ 14756360310001650255

3. J. Smith, Pharmacol. Commun. (1996). https://doi.org/10.1111/j. 2042-7158.1996.tb00522.x

4. E. Buxbaum, Inhibition and Inactivation of Enzymes (Springer, Cham, 2015). https://doi.org/10.1007/978-3-319-19920-7_6

5. W. Sneader, BMJ (2000). https://doi.org/10.1136/bmj.321.7276. 1591

6. B.J.B. Wood, L.L. Ingraham, Nature (1965). https://doi.org/10. 1038/205291a0

7. R.R. Rando, Science (1974). https://doi.org/10.1097/EDE.0b013 e3181

8. C.H. Ramirez-Ronda, J.P. Sanford, Arch. Otolaryngol. (1975). https://doi.org/10.1001/archotol.1975.00780330031008

9. R.H. Abeles, A.L. Maycock, Acc. Chem. Res. (1976). https://doi. org/10.1021/ar50105a001

10. R.F. Pratt, Bioorg. Med. Chem. Lett. (1992). https://doi.org/10. 1016/S0960-894X(00)80506-5

11. K. Nazari, A. Mahmoudi, M. Khosraneh, Z. Haghighian, A.A. Moosavi-Movahedi, J. Mol. Catal. B Enzym. (2009). https://doi. org/10.1016/j.molcatb.2008.04.008

12. A. Sadana, Biotechnol. Adv. (1988). https://doi.org/10.1016/ 0734-9750(88)91890-3

13. B.R. Baker, Annu. Rev. Pharmacol. (1970). https://doi.org/10. 1146/annurev.pa.10.040170.000343

14. B.W. Metcalf, Proteins Based a Symposium Sponsored by the Division of Agricultural and Food Chemistry. ACS/CSJ Chemical Congress, Honolulu, Hawaii, April 4-5, ACS Publications (1980) https://doi.org/10.1021/bk-1980-0123.ch011

15. M.A. Ator, The Enzymes (Academic Press, London, 1990). https://doi.org/10.1016/S1874-6047(08)60198-5

16. C. Helvig, N. Tijet, I. Benveniste, F. Pinot, J.P. Salaün, F. Durst, Methods Enzymol. (2002). https://doi.org/10.1016/S00766879(02)57693-X
17. R.R. Rando, Methods in Enzymology (Academic Press, London, 1977). https://doi.org/10.1016/S0076-6879(77)46016-6

18. K.F. Tipton, ELS (2001). https://doi.org/10.1038/npg.els.00006 01

19. C.T. Walsh, Annu. Rev. Biochem. (1984). https://doi.org/10. 1146/annurev.bi.53.070184.002425

20. B.W. Metcalf, Annu. Rep. Med. Chem. (1981). https://doi.org/ 10.1016/S0065-7743(08)61293-2

21. M.A. Moruno-Dávila, C. Garrido-del Solo, M. Garcia-Moreno, F. Garcia-Cánovas, R. Varón, BioSystems (2001). https://doi. org/10.1016/S0303-2647(01)00117-4

22. J.W. Shay, W.E. Wright, Cancer Cell (2005). https://doi.org/ 10.1016/j.ccr.2004.12.012

23. A. Maresca, C. Temperini, H. Vu, N.B. Pham, S.A. Poulsen, A. Scozzafava, R.J. Quinn, C.T. Supuran, J. Am. Chem. Soc. (2009). https://doi.org/10.1021/ja809683v

24. X. Tan, F. Soualmia, L. Furio, J.F. Renard, I. Kempen, L. Qin, M. Pagano, B. Pirotte, C. El Amri, A. Hovnanian, M. ReboudRavaux, J. Med. Chem. (2015). https://doi.org/10.1021/jm500 988d

25. D.J. Leaver, P. Patkar, U.K. Singha, M.B. Miller, B.A. Haubrich, M. Chaudhuri, W.D. Nes, Chem. Biol. (2015). https:// doi.org/10.1016/j.chembiol.2015.08.017

26. Y. Ichimaru, T. Fujii, H. Saito, M. Sano, T. Uchiyama, S. Miyairi, Bioorg. Med. Chem. (2017). https://doi.org/10.1016/j. bmc.2017.07.009

27. A.H. Yang, X. He, J.X. Chen, L.N. He, C.H. Jin, L.L. Wang, F.L. Zhang, L.J. An, Chem. Biol. Interact. (2015). https://doi. org/10.1021/ja809683v

28. T. Usia, H. Iwata, S. Kadota, Y. Tezuka, J. Ethnopharmacol. (2006). https://doi.org/10.1016/j.jep.2005.12.001

29. D.S. Johnson, E. Weerapana, B.F. Cravatt, Future Med. Chem. (2010). https://doi.org/10.1021/ja809683v

30. K.S. Cheung, S.A. Wasserman, E. Dudek, S.A. Lerner, M. Johnston, J. Med. Chem. (1983). https://doi.org/10.1021/jm003 $66 \mathrm{a} 015$

31. M.E. Kidane, B.H. Vanderloop, W. Zhou, C.D. Thomas, E. Ramos, U. Singha, M. Chaudhuri, W.D. Nes, J. Lipid Res. (2017). https://doi.org/10.1194/jlr.M079418

32. T.M. Penning, Trends Pharmacol. Sci. (1983). https://doi.org/ 10.1016/0165-6147(83)90369-3

33. C. Trefzer, H. Škovierová, S. Buroni, A. Bobovská, S. Nenci, E. Molteni, F. Pojer, M.R. Pasca, V. Makarov, S.T. Cole, G. Riccardi, J. Am. Chem. Soc. (2012). https://doi.org/10.1021/ ja211042r

34. C.C. Wang, J. Cell Biochem. (1991). https://doi.org/10.1002/ jcb. 240450111

35. T.S. Chang, J. Agric. Food Chem. (2007). https://doi.org/10. 1021/jf063095i

36. L. Pochet, R. Frédérick, B. Masereel, Curr. Pharm. Des. (2004). https://doi.org/10.2174/1381612043382684

37. K.H. Verschueren, K. Pumpor, S. Anemüller, S. Chen, J.R. Mesters, R. Hilgenfeld, Chem. Biol. (2008). https://doi.org/ 10.1016/j.chembiol.2008.04.011

38. D. Vercammen, B. Belenghi, B. Van De Cotte, T. Beunens, J.A. Gavigan, R. De Rycke, A. Brackenier, D. Inzé, J.L. Harris, F. VanBreusegem, J. Mol. Biol. (2006). https://doi.org/10.1016/j. jmb.2006.09.010

39. A. Garcia-Jimenez, F. García-Molina, J.A. Teruel-Puche, A. Saura-Sanmartin, P.A. Garcia-Ruiz, A. Ortiz-Lopez, J.N. Rodríguez-López, F. Garcia-Canovas, J. Munoz-Munoz, Int. J. Biol. Macromol. (2018). https://doi.org/10.1016/j.ijbiomac. 2018.07.173

40. J.L. Muñoz-Muñoz, F. Garcia-Molina, J. Berna, P.A. Garcia-Ruiz, R. Varon, J. Tudela, J.N. Rodriguez-Lopez, F. 
Garcia-Canovas, BBA Proteins Proteom. (2012). https://doi. org/10.1016/j.bbapap.2012.02.001

41. R.R. Rando, Biochem. Pharmacol. (1975). https://doi.org/10. 1016/0006-2952(75)90055-6

42. R.R. Rando, Acc. Chem. Res. (1975). https://doi.org/10.1021/ ar50092a004

43. P. Marcotte, C. Walsh, Biochemistry (1976). https://doi.org/10. 1021/bi00659a021

44. K. Maeyama, T. Watanabe, Y. Taguchi, A. Yamatodani, H. Wada, Biochem. Pharmacol. (1982). https://doi.org/10.1016/00062952(82)90531-7

45. L.S.L. Gan, A.L. Acebo, W.L. Alworth, Biochemistry (1984). https://doi.org/10.1021/bi00312a006

46. I.V. Bijnsdorp, E.M. Comijn, J.M. Padron, W.H. Gmeiner, G.J. Peters, Oncol. Rep. (2007). https://doi.org/10.3892/or.18.1.287

47. S.S. Tang, D.E. Simpson, H.M. Kagan, J. Biol. Chem. (1984). https://doi.org/10.1016/S0021-9258(17)43553-8

48. K. Wimalasena, D.C. Haines, Anal. Biochem. (1996). https://doi. org/10.1006/abio.1996.0069

49. G. Ricci, F. De Maria, G. Antonini, P. Turella, A. Bullo, L. Stella, G. Filomeni, G. Federici, A.M. Caccuri, J. Biol. Chem. (2005). https://doi.org/10.1074/jbc.M503295200

50. M. Numazawa, M. Nagaoka, W. Handa, Y. Ogawa, S. Matsuoka, J. Steroid Biochem. Mol. Biol. (2007). https://doi.org/10.1016/j. jsbmb.2007.03.042

51. K. Bloch, J. Protein Chem. (1986). https://doi.org/10.1007/ BF01025190

52. K. Bloch, Acc. Chem. Res. (1969). https://doi.org/10.1021/ar500 $19 \mathrm{a} 001$

53. R.R. Rando, Methods Enzymol. 46, $28-41$ (1977). https://doi. org/10.1016/S0076-6879(77)46007-5

54. R.R. Rando, Trends Pharmacol. Sci. (1979). https://doi.org/10. 1016/0165-6147(79)90060-9

55. C. Walsh, Tetrahedron (1982). https://doi.org/10.1016/00404020(82)85068-0

56. C. Walsh, Chemical Recognition in Biology (Springer, Berlin, 1980). https://doi.org/10.1007/978-3-642-81503-4_5

57. J. Tudela, F.G. Cánovas, R. Varón, F.G. Carmona, J. Gálvez, J. Lozano, BBA Protein Struct. Mol. Enzymol. (1987). https://doi. org/10.1016/0167-4838(87)90046-X

58. Z.X. Wang, J. Theor. Biol. (1990). https://doi.org/10.1016/ S0022-5193(05)80261-9

59. F.G. Cánovas, J. Tudela, C.M. Madrid, R. Varón, F.G. Carmona, J. Lozano, BBA Protein Struct. Mol. Enzymol. (1987). https:// doi.org/10.1016/0167-4838(87)90047-1

60. M. Ghadermarzi, A.A. Moosavi-Movahedi, J. Enzym. Inhib. (1996). https://doi.org/10.3109/14756369609030310

61. H.S. Tehrani, A.A. Moosavi-Movahedi, Prog. Biophys. Mol. Biol. (2018). https://doi.org/10.1016/j.pbiomolbio.2018.03.001

62. A.A. Moosavi-Movahedi, K. Nazari, M. Ghadermarzi, Ital. J. Biochem. 48(1), 9-17 (1999)

63. R. Varon, M. Garcia, F. Garcia-Canovas, J. Tudella, J. Mol. Catal. A Chem. (1990). https://doi.org/10.1016/0304-5102(90)85091-U

64. A.A. Saboury, A. Divsalar, G. Ataie, M. Amanlou, A.A. Moosavi-Movahedi, G.H. Hakimelahi, Acta Biochim. Pol. (2003). https://doi.org/10.18388/abp.2003_3676

65. M. Ghadermarzi, A.A. Moosavi-Movahedi, Ital. J. Biochem. 46(4), 197-205 (1997)

66. A.V. Onufriev, E. Alexov, Q. Rev. Biophys. (2013). https://doi. org/10.1017/S0033583513000024

67. J.T. Stivers, C. Abeygunawardana, A.S. Mildvan, G. Hajipour, C.P. Whitman, Biochemistry (1996). https://doi.org/10.1021/ bi9510789

68. M.G. Moreno, R. Varón, A.S. Gracia, J. Tudela, F.G. Cánovas, BBA Protein Struct. Mol. Enzymol. (1994). https://doi.org/10. 1016/0167-4838(94)90246-1
69. M. Khosraneh, A. Mahmoudi, H. Rahimi, K. Nazari, A.A. Moosavi-Movahedi, J. Enzyme Inhib. Med. Chem. (2007). https://doi.org/10.1080/14756360701270683

70. M. Ghadermarzi, A.A. Moosavi-Movahedi, M. Ghadermarzi, BBA Protein Struct. Mol. Enzymol. (1999). https://doi.org/10. 1016/S0167-4838(99)00021-7

71. T. Gefflaut, C. Blonski, J. Perie, M. Willson, Prog. Biophys. Mol. Biol. (1995). https://doi.org/10.1016/0079-6107(95) 00008-9

72. A. Mahmoudi, K. Nazari, M. Khosraneh, B. Mohajerani, V. Kelay, A.A. Moosavi-Movahedi, Enzyme Microb. Technol. (2008). https://doi.org/10.1016/j.enzmictec.2008.06.003

73. K. Sakaki, K. Ohishi, T. Shimizu, I. Kobayashi, N. Mori, K. Matsuda, T. Tomita, H. Watanabe, K. Tanaka, T. Kuzuyama, M. Nishiyama, Nat. Chem. Biol. (2020). https://doi.org/10.1038/ s41589-019-0461-9

74. S. Mandal, S.K. Mandal, Eur. J. Pharmacol. (2009). https://doi. org/10.1016/j.ejphar.2009.06.065

75. R.R. Rando, Annu. Rep. Med. Chem. (1974). https://doi.org/10. 1016/S0065-7743(08)61446-3

76. C.T. Walsh, Trends Biochem. Sci. (1983). https://doi.org/10. 1016/0968-0004(83)90352-3

77. G.R. Stark, P.A. Bartlett, Pharmacol. Ther. (1983). https://doi. org/10.1016/0163-7258(83)90026-8

78. M.C. Monti, A. Casapullo, R. Riccio, L. Gomez-Paloma, FEBS Lett. (2004). https://doi.org/10.1016/j.febslet.2004.10.100

79. L. Garuti, M. Roberti, G. Bottegoni, Curr. Med. Chem. (2011). https://doi.org/10.2174/092986711796391705

80. R.R. Ramsay, K.F. Tipton, Molecules (2017). https://doi.org/10. 3390/molecules22071192

81. K. Miki, M. Xu, A. Gupta, Y. Ba, Y. Tan, W. Al-Refaie, M. Bouvet, M. Makuuchi, A.R. Moossa, R.M. Hoffman, Can. Res. (2001). https://doi.org/10.1093/jnci/88.20.1442

82. Y.H. Mekaj, F.T. Daci, A.Y. Mekaj, Ther. Clin. Risk Manag. (2015). https://doi.org/10.2147/TCRM.S92222

83. D.L. Rolnik, K.H. Nicolaides, Am. J. Obstet. Gynecol. (2020). https://doi.org/10.1016/j.ajog.2020.08.045

84. C. Patrono, C. Baigent, J. Hirsh, G. Roth, Chest (2008). https:// doi.org/10.1378/chest.08-0672

85. M.J. Lucido, B.J. Orlando, A.J. Vecchio, M.G. Malkowski, Biochemistry (2016). https://doi.org/10.1021/acs.biochem.5b01378

86. E.V. Paez Espinosa, J.P. Murad, F.T. Khasawneh, Thrombosis (2012). https://doi.org/10.1155/2012/173124

87. T. Pillaiyar, M. Manickam, V. Namasivayam, Y. Hayashi, S.H. Jung, J. Med. Chem. (2016). https://doi.org/10.1021/acs.jmedc hem. 5 b01461

88. C.A.C. Hyde, S. Missailidis, Int. Immunopharmacol. (2009). https://doi.org/10.1016/j.intimp.2009.02.003

89. D. Li, J. Hu, D. Li, W. Yang, S.F. Yin, R. Qiu, Top. Curr. Chem. (2021). https://doi.org/10.1007/s41061-020-00318-2

90. S. Tomar, M.L. Johnston, S.E.S. John, H.L. Osswald, P.R. Nyalapatla, L.N. Paul, A.K. Ghosh, M.R. Denison, A.D. Mesecar, J. Biol. Chem. (2015). https://doi.org/10.1074/jbc.M115. 651463

91. K. Fan, P. Wei, Q. Feng, S. Chen, C. Huang, L. Ma, B. Lai, J. Pei, Y. Liu, J. Chen, L. Lai, J. Biol. Chem. (2004). https://doi.org/10. 1074/jbc.M310875200

92. P.H. Liang, Curr. Top. Med. Chem. (2006). https://doi.org/10. 2174/156802606776287090

93. Q. Zhao, S. Li, F. Xue, Y. Zou, C. Chen, M. Bartlam, Z. Rao, J. Virol. (2008). https://doi.org/10.1128/jvi.00298-08

94. X. Xue, H. Yu, H. Yang, F. Xue, Z. Wu, W. Shen, J. Li, Z. Zhou, Y. Ding, Q. Zhao, X.C. Zhang, Structures of two coronavirus main proteases: implications for substrate binding and antiviral drug design. J. Virol. (2008). https://doi.org/10.1128/JVI. 02114-07 
95. T.W. Lee, M.M. Cherney, C. Huitema, J. Liu, K.E. James, J.C. Powers, L.D. Eltis, M.N. James, J. Mol. Biol. (2005). https://doi. org/10.1016/j.jmb.2005.09.004

96. A. Kilianski, A.M. Mielech, X. Deng, S.C. Baker, J. Virol. (2013). https://doi.org/10.1128/jvi.02105-13

97. A.O. Adedeji, S.G. Sarafianos, Future Med. Chem. (2013). https://doi.org/10.4155/fmc.13.183

98. R.S. Oremland, D.G. Capone, Adv. Microb. Ecol. (1988). https:// doi.org/10.1007/978-1-4684-5409-3_8

99. J. Chapman, A.E. Ismail, C.Z. Dinu, Catalysts (2018). https:// doi.org/10.3390/catal8060238

100. T.S. Chang, Int. J. Mol. Sci. (2009). https://doi.org/10.3390/ijms1 0062440

101. S. Zolghadri, A. Bahrami, M.T. Hassan Khan, J. Munoz-Munoz, F. Garcia-Molina, F. Garcia-Canovas, A.A. Saboury, J. Enzyme Inhib. Med. Chem. (2019). https://doi.org/10.1080/14756366. 2018.1545767

102. P.G. Yap, C.Y. Gan, Foods. (2021). https://doi.org/10.1016/j.ccr. 2004.12.012

103. A. Slominski, M.A. Zmijewski, J. Pawelek, Pigm. Cell Melanoma Res. (2012). https://doi.org/10.1111/j.1755-148X.2011.00898.x

104. C. Wu, Z. Li, C. Wang, Y. Zhou, T. Sun, Process Res. Dev. (2018). https://doi.org/10.1021/acs.oprd.8b00070
105. A. Vogel, Enzyme Development Technologies (Wiley, Chichester, 2019). https://doi.org/10.1002/9783527813780.ch1_2

106. H.P. Schweizer, Biotechniques (2008). https://doi.org/10.2144/ 000112807

107. H. Xiao, Z. Bao, H. Zhao, Ind. Eng. Chem. Res. (2015). https:// doi.org/10.1021/ie503060a

108. H. Gharibi, Z. Moosavi-Movahedi, S. Javadian, K. Nazari, A.A. Moosavi-Movahedi, J. Phys. Chem. B (2011). https://doi.org/10. 1021/jp112051t

109. Y. Sefidbakht, K. Nazari, F. Farivar, Z. Moosavi-Movahedi, N. Sheibani, A.A. Moosavi-Movahedi, J. Iran. Chem. Soc. (2012). https://doi.org/10.1007/s13738-011-0040-9

110. Z. Moosavi-Movahedi, H. Gharibi, H. Hadi-Alijanvand, M. Akbarzadeh, M. Esmaili, M.S. Atri, Y. Sefidbakht, M. Bohlooli, K. Nazari, S. Javadian, J. Hong, J. Biomol. Struct. Dyn. (2015). https://doi.org/10.1080/07391102.2014.1003196

111. H.A. Kermani, A. Shockravi, Z. Moosavi-Movahedi, A. KhalafiNezhad, S. Behrouz, F.Y. Tsai, G.H. Hakimelahi, A. Seyedarabi, A.A. Moosavi-Movahedi, J. Iran. Chem. Soc. (2013). https://doi. org/10.1007/s13738-013-0233-5 